Short Title: Steel slag improves soil fertility and rice yield

\title{
STEEL SLAG AMENDMENT INCREASES NUTRIENT AVAILABILITY AND RICE YIELD IN A SUBTROPICAL PADDY FIELD IN CHINA
}

\author{
By WEIQI WANG ${ }^{1,2 *}$, JORDI SARDANS ${ }^{3,4 *}$, CHUN WANG ${ }^{1,2}$, CONGSHENG \\ ZENG $^{1,2}$, CHUAN TONG $^{1,2}$, MIREIA BARTRONS ${ }^{3,4}$, JOSEP PEÑUELAS ${ }^{3,4}$ \\ ${ }^{1}$ Institute of Geography, Fujian Normal University, Fuzhou 350007, China; ${ }^{2}$ Key \\ Laboratory of Humid Subtropical Eco-geographical Process, Ministry of Education, \\ Fujian Normal University, Fuzhou 350007, China: ${ }^{3}$ CSIC, Global Ecology CREAF- \\ CSIC-UAB, Cerdanyola del Valles, 08193 Barcelona, Catalonia, Spain; ${ }^{4}$ CREAF, \\ Cerdanyola del Valles, 08193 Barcelona, Catalonia, Spain. \\ *Corresponding authors: wangweiqi15@163.com; j.sardans@creaf.uab.cat

\section{SUMMARY}

Rice is the main food for most of the human population, so sustainable rice production is very important for food security. The fertility of the soil in paddy fields is the key factor controlling rice growth and production. Steel slag amendment is becoming an effective method to increase the soil fertility, stabilize rice production, and reduce greenhouse-gas emissions in Asiatic paddy fields (i.e. Korea, Japan, Bangladesh, and China). We studied the relationships of steel slag amendment with plant-soil nutrient allocation, stoichiometry, and rice yield in a paddy field in subtropical China. Amendment was associated with higher soil $\mathrm{N}$ and $\mathrm{P}$ availability, lower available-N:available-P ratio, and higher available $\mathrm{Ca}$ and $\mathrm{Si}$ concentrations. Increases in $\mathrm{P}, \mathrm{Ca}$, and $\mathrm{Mg}$ availability were correlated with high yields. High yields under steel slag amendment were also associated with high foliar and stem $\mathrm{N}$ and $\mathrm{P}$ concentrations and lower $\mathrm{N}: \mathrm{P}$ ratios and with high shoot/root $\mathrm{N}$ and $\mathrm{P}$ concentration ratios, traits that are typically associated with productive ecosystems able to support species with high growth rates. The positive correlation between steel slag application and yield was partially due to an indirect effect (35\% of the total effect) of enhancement of soil $\mathrm{Ca}, \mathrm{Si}$, and $\mathrm{P}$ availability, which were positively correlated with yield. Steel slag amendment in this paddy field increased plant growth and yield by enhancing nutrient availability, altering soil and plant stoichiometry, and shifting stem:root nutrient allocation.

Keywords: Nitrogen; N:P; Phosphorus; Soil; Stoichiometry.

This article has been published in a revised form in Experimental agriculture. DOI 10.1017/S0014479717000412. This version is free to view and download for private research and study only. Not for re-distribution, re-sale or use in derivative works. (C) Cambridge Univesity Press 


\section{INTRODUCTION}

Rice is the major cereal crop for more than half of the world's population. FAO (2009) estimated that rice production needed to increase by $40 \%$ by 2030 to meet the rising demand from the increasing population. Soil fertility improvement is an important factor for increasing rice production (Ali et al., 2014). Several strategies for agricultural management are being tested for achieving both sustainable rice production and adequate soil fertility such as straw biochar (Zhao et al., 2014), anaerobically digested cattle manure (Nishikawa et al., 2012), rice straw (Zhang et al., 2013), crop rotation (Nishida et al., 2013), and silicate fertilization (Lee et al., 2012). Rice is the base of the diet for $60 \%$ of the Chinese population, so the protection of rice production has a pivotal role for food security (Zhu, 2006). Rice cultivation accounts for approximately $28 \%$ of the total area of crop cultivation, and total rice production accounts for approximately $38 \%$ of the total China crop production (Zhu, 2006). Ninety percent of the paddy fields in China are located in subtropical regions, such as the provinces of Fujian, Jiangxi, and Hunan. The development of methods for increasing soil fertility and sustaining productivity without jeopardizing environmental health in subtropical regions of China is therefore important.

The accumulation of industrial waste is a major environmental problem in urban areas and its rational use is the most effective way to solve such problem (Montejo et al., 2013). Steel slag is an important waste product of the steel industry, with a total production of $90 \times 10^{6}$ tons in China (Yi et al., 2012) and only $22 \%$ of this amount used for other economical or environmental activities (Yi et al., 2012). Slag contains mainly calcium $(\mathrm{Ca})$ and silicon $(\mathrm{Si})$, which can reach more than $70 \%$ of the total weight, whereas the $\mathrm{N}$ and $\mathrm{P}$ concentrations are 10.33 and $0.07 \mathrm{mg} \mathrm{g}^{-1}$, respectively (Lan et al., 2015). Previous studies have found that steel slag amendment increased soil fertility and rice growth, yield, and grain quality (Wang et al., 2013). The effects of slag application on soil fertility and rice growth and yield in subtropical paddy fields, however, have been less well studied. C, N and P interact strongly and other nutrients such as $\mathrm{Ca}$ and $\mathrm{Mg}$ can be limiting in some terrestrial ecosystems (Baribault et al., 2012; Lapenis et al., 2013; Naples and Fisk, 2010). Thus extra $\mathrm{Ca}$ and $\mathrm{Si}$ inputs as well as moderate amounts of $\mathrm{N}$ and $\mathrm{P}$ would change concentration, availability and stoichiometry of soil nutrients and then affect plant growth (Sardans et al., 2012a; 2012b). Plant growth is generally N limited in Chinese wetlands (Zhang et al., 2013), especially in paddy fields as periodic inundation limits the access to nutrients due to impaired root metabolism under hypoxia (Kirwan and Guntenspergen, 2012), there is reduction of mineralization rates (Adame et al., 2010) and increases in nutrient leaching (Kobayashi et al., 2009). The improvement of nutrient availability in paddy fields by sustainable practices would substantially improve rice production.

Increases in rice production due to the application of steel slag have been found (Carvalho-Pupatto et al., 2004; Ning et al., 2014; Wang et al., 2015), with increases in root growth (Carvalho-Pupatto et al., 2004) and decreases in the bioavailability of soil trace elements (Gu et al., 2011). Steel slag application can increase the resistance against diseases (Gu et al., 2011; Ning et al., 2014) and decrease the emission of greenhouse gases (Wang et al., 2015). Data, however, are not available for the effects of steel slag application on $\mathrm{C}, \mathrm{N}$, and $\mathrm{P}$ concentrations and stoichiometry of the plant-soil system in rice croplands. Specifically, it is not known if steel slag amendment affects rice production and nutrient stoichiometry by altering the soil nutrient concentrations. We hypothesized that changes of nutrient concentrations in different plant organs and in the entire plant could provide a more realistic view of the role of nutrient concentrations and stoichiometric relationships on growth and other ecophysiological traits than focusing 
only on foliar stoichiometry. Several studies have noticed that the inclusion of more organs in ecological stoichiometry studies can drastically affect the relationships of stoichiometry with other ecophysiological traits (Elser et al., 2003; Sardans et al., 2012a).

The present study was carried out in subtropical paddy fields in Fujian Province, China. We chose steel slag from the steel industry as the test material to improve soil nutrients and rice production. We previously reported that steel slag was an effective amendment for increasing rice yields in a subtropical paddy field in Fujian Province (Wang et al., 2013), but the effect of steel slag application on plant and soil nutrient concentrations and stoichiometries and their relationships with the increasing yields remain unknown. The present study examined the effect of steel slag amendment on soil and rice nutrient concentrations and stoichiometries in a subtropical paddy field in southeastern China. Specifically, we studied the effects during the growing season of different amounts of steel slag amendments on soil nutrient concentrations and C:N, C:P, and N:P ratios in rice leaves, stems, and roots; and examined the relationships between yield and changes in nutrient uptake, allocation to different organs, and concentrations and stoichiometries in the plant-soil system.

\section{MATERIALS AND METHODS}

\section{Study site}

All field experiments were carried out in the Wufeng Agronomy Field of the Fujian Academy of Agricultural Sciences (Supplementary Material Fig S1) in a subtropical region of southeastern China. The characteristics and historical management of the field site have been described by Wang et al. (2015). The soil of the paddy field was moist, poorly drained, and had a ratio of sand:silt:clay of 28:60:12 (Wang et al., 2013). The bulk density of the soil before the study was $1.1 \mathrm{~g} \mathrm{~cm}^{-3}$. The soil had a $\mathrm{pH}\left(1: 5\right.$ with $\left.\mathrm{H}_{2} \mathrm{O}\right)$ of 6.5 and concentrations of organic carbon, total nitrogen, and total phosphorus were 18.1, 1.2 , and $1.1 \mathrm{~g} \mathrm{~kg}^{-1}$, respectively (Wang et al., 2012). The water level was maintained at 5$7 \mathrm{~cm}$ above the soil surface during the periods of rice growth by an automatic water-level controller, and the paddy field was drained two weeks before harvesting. Fertilization consisted of a mix of NPK $\left(\mathrm{N}: \mathrm{P}_{2} \mathrm{O}_{5}: \mathrm{K}_{2} \mathrm{O}\right.$ at 16:16:16\%, Keda Fertilizer Co., Ltd., Shandong, China) and urea $(46 \% \mathrm{~N})$ fertilizers applied to the crops at rates of 95,70 , and $70 \mathrm{~kg} \mathrm{ha}^{-1}$ of $\mathrm{N}, \mathrm{P}_{2} \mathrm{O}_{5}$, and $\mathrm{K}_{2} \mathrm{O}$, respectively, in each of three growth phases: before transplantation, at tillering, and at panicle formation (Wang et al., 2015).

\section{Experimental design and treatments}

Our study period was from 16 April to 17 July 2011, which is the first of the two yearly periods of rice crop. The field was plowed to a depth of $15 \mathrm{~cm}$ with a moldboard plow on 12 April 2011 and flooded on 14 April 2011. The rice (scientific name?) variety was Hesheng 10, and the spacing between rows was $28 \mathrm{~cm}$ and between plants in the row was $14 \mathrm{~cm}$. Three replicates of four treatment plots $\left(50 \mathrm{~m}^{2}\right.$ each) were arranged in a randomized block design. The slag was granular $(<2 \mathrm{~mm}$ in diameter $)$, with a $\mathrm{pH}$ of 8.5 (when dissolved in water) and composed mainly of $\mathrm{CaO}(34.9 \%), \mathrm{SiO}_{2}(40.7 \%)$, and $\mathrm{Fe}_{2} \mathrm{O}_{3}$ (4.8\%) (Wang et al., 2012), which was similar to slags used in previous studies (Wang et al., 2013). The slag was applied to the paddy field at 0 (control), 2, 4, and $8 \mathrm{Mg}$ $\mathrm{ha}^{-1}$, equivalent to the addition of $0,67.2,134$, and $269 \mathrm{~kg} \mathrm{Fe} \mathrm{ha}^{-1}$, respectively, two days before rice transplantation. All control and amended plots followed the same scheme of crop management, including conventional fertilization. A total of 84 soil samples (four treatments $\times$ three replicates $\times$ seven evaluation dates) were collected. Rice stems, leaves, and root $(0-15 \mathrm{~cm})$ biomasses were collected from random $0.25 \times 0.25 \mathrm{~m}$ quadrats in all 
plots immediately after transplantation and then every two weeks until harvest. Plant material was gently washed with water. A total of 252 plant samples (four treatments $\times$ three replicates $\times$ seven evaluation dates $\times$ three organs) were thus collected. Shoot, root, and total biomasses and yield were determined at harvest (15 July 2011).

\section{Sampling and chemical analyses of plant and soil samples}

Both above- and below-ground samples were oven-dried $\left(80^{\circ} \mathrm{C}\right.$ for $\left.24-36 \mathrm{~h}\right)$ to a constant weight and weighed. Plant $\mathrm{C}$ and $\mathrm{N}$ concentrations were determined using a Vario EL III Elemental Analyzer (Elementar Scientific Instruments, Hanau, Germany), and $\mathrm{P}$ concentration was measured by perchloric-acid digestion followed by molybdateblue reaction using a UV-2450 spectrophotometer (Shimadzu Scientific Instruments, Kyoto, Japan) (Lu, 1999).

Core soil samples were collected from the top layers $(0-30 \mathrm{~cm})$ of all plots the day after transplantation and then every two weeks until harvest. The samples were divided into two parts, one maintained fresh for evaluating the microbial biomass carbon (MBC) and dissolved organic carbon (DOC), and the other air-dried (in the shade) for measuring all other physicochemical characteristics after removing all roots and other plant components. Soil properties were determined following the methods of $\mathrm{Lu}$ (1999). Soil MBC concentration was determined by fumigation-extraction ( $\mathrm{Lu}, 1999)$. DOC concentration was determined by extraction with 1:5 soil:deionized water $(\mathrm{Lu}, 1999)$ and measured using an TOC-V CPH total carbon analyzer (Shimadzu Scientific Instruments, Kyoto, Japan). Available-N concentrations were determined by diffusion using alkaline hydrolysis (Lu, 1999), while available-P concentrations were determined by extraction with $0.5 \mathrm{~mol} \mathrm{~L}^{-1} \mathrm{NaHCO}_{3}$ and then measured by Mo-Sb colorimetry (Lu, 1999). Available-K concentrations were determined by extraction with $1 \mathrm{~mol} \mathrm{~L}^{-1} \mathrm{NH}_{4} \mathrm{Ac}$ (Lu, 1999) and then measured by FP 640 flame photometry (Shanghai Electronic Technology Instruments, Shanghai, China)."Available-Si concentrations were determined by silicon molybdenum blue colorimetry ( $\mathrm{Lu}, 1999)$. Available-Ca and $-\mathrm{Mg}$ concentrations were determined by EDTA titration (Lu, 1999).

\section{Statistical analyses}

All statistical analyses were performed using SPSS 19.0 (SPSS Inc., Chicago, USA). The differences of all plant and soil variables among control and different amendments were analyzed by repeated-measures analyses of variance. The relationships among the concentrations and stoichiometries of the various nutrients in the plant above- and belowground samples, and the relationships of rice yield and shoot, root, and total biomasses with nutrient concentrations and stoichiometries in the soil and plant samples, were examined by Pearson correlation analysis. For these relationships data from all the experimental treatments were used, except for the correlations with yield in which only the final data was used. We used Hochberg and Benjanimi (1990) correction for the correction of type I error in multiple regressions. We performed multivariate statistical analyses using functional discriminant analysis (FDA) to determine the importance of soil $\mathrm{Ca}, \mathrm{Si}, \mathrm{K}, \mathrm{Mg}, \mathrm{N}$, and $\mathrm{P}$ availabilities; $\mathrm{DOC}$ and $\mathrm{MBC}$ concentrations; the ratios of DOC:available N, DOC:available $\mathrm{P}$, and available N:available $\mathrm{P}$; foliar, stem, and root $\mathrm{N}$, $\mathrm{P}$, and $\mathrm{C}$ concentrations and $\mathrm{C}: \mathrm{N}, \mathrm{C}: \mathrm{P}$, and $\mathrm{N}: \mathrm{P}$ concentration ratios; foliar, stem, root, and total biomasses; and rice yield as variables. The FDA was performed using Statistica 6.0 (StatSoft Inc., Tulsa, USA). C:N, C:P, and N:P ratios were calculated as mass ratios. We selected the soil and plant variables strongly correlated with slag amendment and rice yield by structural equation modeling. We thus analyzed the total, direct, and indirect effects of slag amendment on rice yield by the relationships between amendment and the 
chemical traits of soil and plants. We fitted the various models using the sem $\mathrm{R}$ package (Fox et al., 2013) and determined the minimum adequate model using Akaike's information criterion (Akaike, 1974). Standard errors and significance levels $(\mathrm{P})$ of the total, direct, and indirect effects were calculated using bootstrapping (1200 repetitions).

\section{RESULTS}

\section{Effect of slag amendment on the soil and plant nutrient concentrations and ratios}

Soil available-N, -P, -Si, and -Ca concentrations were significantly higher under slag amendment than in the control, whereas soil DOC:available-P ratios (Table 1, Fig. S2 and S3) and foliar C concentrations (Table 1, Figs. S4 and S5) were on average lower under slag application throughout the experimental period.

\section{Relationships of $C: N, C: P$, and $N: P$ ratios between soil and rice plants}

Foliar, stem, and root $\mathrm{C}: \mathrm{N}$ ratios were positively correlated with the soil DOC:available-N ratio (Table $\mathrm{S} 1$ ), whereas foliar, stem, and root $\mathrm{N}: \mathrm{P}$ ratios were positively correlated with the soil available-N:available-P ratio (Table $\mathrm{S} 1$ ). On the other hand, foliar, stem, and root C:P ratios were negatively correlated with the soil DOC:available-P ratio (Table $\mathrm{S} 1$ ).

\section{Relationships of crop yield with $C, N$, and $P$ availabilities}

Rice yield was correlated positively with soil available-P, - $\mathrm{Si}$, and -Ca concentrations, foliar and stem $\mathrm{N}$ and $\mathrm{P}$ concentrations, and root $\mathrm{C}: \mathrm{N}$ ratio (Table 2). Negative correlations were found between yield and soil available-Mg concentration. Shoot, root and total biomass were correlated positively with soil available-N, -P, $-\mathrm{Si}$, and -Ca concentrations, foliar and stem $\mathrm{N}$ and $\mathrm{P}$ concentrations, and root $\mathrm{C}: \mathrm{P}$ and $\mathrm{N}: \mathrm{P}$ ratios. Yield, and shoot, root and total biomass were positively correlated with $\mathrm{N}$ and $\mathrm{P}$ concentrations in leaves and stems but not with the corresponding concentrations in roots that in the case of $\mathrm{N}$ concentrations were negatively correlated with yield, and root and total plant biomass. Stem C:P, C:N and N:P ratio and root $\mathrm{C}: \mathrm{N}$ ratio were also positively correlated with yield and plant biomasses except root $\mathrm{C}: \mathrm{N}$ ratio and shoot biomass. Root $\mathrm{C}: \mathrm{P}$ and $\mathrm{N}: \mathrm{P}$ ratios were positively correlated with shoot biomass.

The application of slag did not change the $\mathrm{C}$ content of whole plants but it was associated with a higher allocation of $\mathrm{C}$ to roots (Table 3 ). In contrast, slag application caused increases in $\mathrm{N}$ and $\mathrm{P}$ contents of whole plants and higher allocation of these nutrients to aboveground plant organs at intermediate levels of application (Table 3).

\section{Multivariate and SEM analyses}

Soils amended with the various levels of slag were well separated in the DFA analyses (Table S2, Figure 1). Rice yield (RY) best explained the DFA grouping factors (different plots of slag amendment). Changes in soil $\mathrm{P}, \mathrm{Ca}, \mathrm{N}$, and $\mathrm{Si}$ availabilities, foliar $\mathrm{N}$ and $\mathrm{P}$ concentrations, and soil and foliar $\mathrm{N}: \mathrm{P}$ ratios were other variables explaining the separation among samples receiving different levels of slag (Table S3, Figure 1). The best structural model explaining the variance in rice yield $\left(\mathrm{R}^{2}=0.69, \mathrm{P}<0.0001\right)$ identified a positive relationship between slag application and yield, partially due to an indirect effect ( $32 \%$ of the total effect) from the enhancement of soil $\mathrm{Ca}, \mathrm{Si}$, and $\mathrm{P}$ availabilities, which were also positively correlated with yield (Figure 2). 


\section{Effect of steel slag amendment on soil and plant nutrients}

Application of steel slag has increased soil Ca-, Si-, N, and P-availability (Table 1), which are consistent with results of previous reports (Wang et al., 2013; Ali et al., 2014). The addition of silicate ions could also increase $\mathrm{N}$ and $\mathrm{P}$ availabilities by displacing nitrogenous ions $\left(\mathrm{NO}_{3}{ }^{-}\right.$and $\left.\mathrm{NH}_{4}{ }^{+}\right)$and phosphates from ligand exchange sites (Lee et al., 2004) and/or by decreasing their sorption on soil colloids (Shariatmadari et al., 1999). The observed increases in soil $\mathrm{pH}$ due to the alkalinity of the slag should also decrease the mobilization of most heavy metals and thus reduce the risk of soil toxicity. There was a strong impact of steel slag fertilization not only in the soil availability of $\mathrm{N}, \mathrm{P}, \mathrm{Ca}$ and $\mathrm{Si}$, but also on crop yield and plant biomass (Table 3 ). Thus the results strongly suggest that this sub-tropical paddy that had historically been managed by conventional fertilization in Fujian had its rice production capacity limited by P, Ca and Si (Figure 2).

Slag can absorb and retain nutrients, slowing nutrient release, preventing leaching and consequent water eutrophication, and improving the capacity of soil to provide nutrients for plant uptake (Zhao, 2012). In fact, the total amount of nutrients stored in plants increased (Table 3) due to the increase of plant growth related to the improved nutrient availability under steel slag fertilization. $\mathrm{Ca}$ and $\mathrm{Si}$ are involved in several metabolic and physiological processes linked to growth, fruit development and defense against pathogens in rice plants (Datnoff et al., 1991; Frattini et al., 1999; Rodrigues et al., 2001,2003; Guntzer et al., 2012; Cacique et al., 2013; Sano et al., 2015). In addition, simultaneous increases in soil availability of several nutrients at once can have positive synergies in crop growth and yield production because the fertilization of one nutrient increases the plant uptake and content of other nutrients (Deren, 1997; He et al., 1999; Kim et al., 2005; Pati et al., 2016).

Soil DOC concentrations decreased with the steel slag application and this decrease is likely related to stabilization (fraction in non-soluble C forms) through combination with $\mathrm{Fe}_{2} \mathrm{O}_{3}$ (Song et al., 2012). In our study, the application of 2, 4, and 8 $\mathrm{Mg} \mathrm{ha}^{-1}$ of steel slag added 96, 192, and $384 \mathrm{~kg} \mathrm{Fe}_{2} \mathrm{O}_{3} \mathrm{ha}^{-1}$, respectively.

\section{Changes in soil and plant nutrient stoichiometry}

The results of this study are in agreement with previous ones in paddy fields, where $\mathrm{N}$ is limiting. In the Minjiang estuary $\mathrm{N}$ limitation have been previously descrived (Wang et al., 2012). The success of the invasive Phragmites australis in a nearby wetland was associated with its higher capacity to resorb $\mathrm{N}$ and increase $\mathrm{N}$-use efficiency (Wang et al., 2014). Consistently with these previous studies the paddy soils in our study had particularly low available-N:available-P ratios (1.6-3.3 on mass basis), which contrasted with the global average of 5.9 (Cleveland and Liptzin, 2007), suggesting that since the point of view of soil $\mathrm{N}: \mathrm{P}$ ratio, $\mathrm{N}$ should be more limiting in our experimental conditions. However, observing the low availability of $\mathrm{N}$ and $\mathrm{P}$ in this soils and the fact that steel slag fertilization increase the concentrations of both nutrients, this should be more important to improve rice growth than the changes of soil available-N:available-P ratio. Moreover, above-/belowground $\mathrm{N}$ ratio (in mass basis) from 11.7 in control plots to 15.9 in plots receiving 2 MG ha-1 of steel slag together with above-/belowground P ratio (in mass basis) from 2.32 in control plots to 2.94 in plots receiving $4 \mathrm{MG} \mathrm{ha}^{-1}$ of steel slag, suggest a greater proportional allocation of $\mathrm{N}$ and $\mathrm{P}$ to leaves versus roots when steel slag fertilization was applied (Tables 1 and 3). Thus steel slag application produces higher $\mathrm{N}$ and $\mathrm{P}$ uptake associated to higher biomass production but not to larger $\mathrm{N}$ and $\mathrm{P}$ concentrations and promotes higher proportional allocation of nutrient sources directly to 
production when certain levels of steel slag are applied as fertilizer. However, the concentrations of $\mathrm{N}$ and $\mathrm{P}$ observed in this study in different rice plant organs are in the same range than those observed in previous studies (Deren, 1997; Lavakush et al., 2014). This together with the fact that steel slag did not increase C:N and C:P ratios, allow to conclude that the observed enhancement of rice plant biomass associated to steel slag was not due to an increase of efficiency in $\mathrm{N}$ - and $\mathrm{P}$-use. Thus, despite $\mathrm{N}$ and $\mathrm{P}$ soil availability and rice plants $\mathrm{N}$ and $\mathrm{P}$ contents (but not concentrations) have increased with steel slag fertilization the overall analysis showed that $\mathrm{N}$ and $\mathrm{P}$ soil availability rise was not the main or at least the unique cause associated with the rise in yield and growth of rice plants receiving steel slag fertilization. In fact, a previous study in this area reported that rice plants retained more $\mathrm{N}$ in plots amended with slag than in the control plots (Zhao, 2012). Our study thus found that steel slag fertilization was not associated with higher $\mathrm{N}$ and $\mathrm{P}$ concentrations but with increases in $\mathrm{N}$ and $\mathrm{P}$ accumulation, and also of $\mathrm{Ca}$ and $\mathrm{Si}$ all them associated with higher availability of all four nutrients in soil by steel slag amendment. Finally, the increases in plant growth and yield associated to steel slag fertilization were mainly related to the increases in soil $\mathrm{P}-, \mathrm{Ca}-$ and $\mathrm{Mg}$-availability (Figure 2). Thus, this wetland area can also be $\mathrm{P}, \mathrm{Si}$ and $\mathrm{Ca}$ limited as SEM analysis showed.The multivariate and SEM analyses also confirmed the positive relationships of slag amendment with plant growth and yield: these relationships were associated with an enhancement of nutrient availability in soil, higher $\mathrm{N}$ and $\mathrm{P}$ contents in plant tissues, and a shift in nutrient allocation between stems and roots. The novelty of our results is that slag application did not alter plant $\mathrm{N}: \mathrm{P}$ ratios, but it changed the nutrient allocation and improved resources use and growth rates. Specifically, changes in soil $\mathrm{P}, \mathrm{Ca}, \mathrm{N}$, and $\mathrm{Si}$ availabilities, foliar $\mathrm{N}$ and $\mathrm{P}$ concentrations, and soil available-N:available-P ratio explained the separation among samples receiving different levels of slag (Figure 1, Tables1-3) and then higher rice yields were related with higher dose of slag application (Figure 1). However, we can not discard the possible potential impacts of slag on soil, groundwater and wildlife or food quality, which must be monitored in agricultural systems. Until now, we have not detected significant impacts of steel slag when considering the most dangerous trace elements (Wang et al., 2015, 2016). However, some negative environmental impacts associated with the use of steel slag at soil and superficial water level have been detected in other regions of China (Meng and Liu, 2000). This last study showed an increase of some trace elements in paddy soils and rice plants mostly in northern regions of China in sites with long-term application of great amounts of steel slag. The establishment of an adequate doselyear to attain optimum results (maximum benefices without negative effects) at medium and long-term warrants further studies.

\section{CONCLUSION}

Steel slag increased soil N, P, Ca, and Si availabilities and rice plant biomass and nutrient contents. The allocation of $N$ and $P$ to aboveground organs also increased, at least at intermediate levels of slag application. This method of fertilization could be applied on a large scale at low cost, because $7.82 \times 10^{8}$ t of steel were produced in China in 2013, and the amount of slag generated was 0.46 t per ton of steel produced (Xie and Xie, 2003). The total amount of steel slag produced in 2013 was thus $3.60 \times 10^{8}$ t, so its application to paddy fields to easily improve rice production and soil conservation in China would be very cost effective..

\section{ACKNOWLEDGMENT}


The authors would like to thank Pengfei Li, Na Zhao, and Dehua Lin for their assistance with field sampling. Funding was provided by the National Science Foundation of China (41571287, 31000209), Natural Science Foundation Key Programs of Fujian Province (2014R1034-3, 2014Y0054, and 2014J01119), Science and Technology Program of Fuzhou City (2014-G-66), the Program for Innovative Research Team at Fujian Normal University (IRTL1205), European Research Council Synergy grant ERC-SyG-2013610028 IMBALANCE-P, Spanish Government grant CGL2016-79836-P, and Catalan Government grant SGR 2014-274.

\section{REFERENCES}

Adame, M. F., Virdi, B. and Lovelock, C. E. (2010). Effect of geomorphological setting and rainfall on nutrient exchange in mangroves during tidal inundation. Marine and Freshwater Research 61:1197-1206.

Akaike, H. (1974). A new look at the statistical model identification. IESS Transactions of Automatic Control 19:716-723.Ali, M. A., Sattar, M. A., Islam, M. N. and Inubushi, K. (2014). Integrated effects of organic, inorganic and biological amendments on methane emission, soil quality and rice productivity in irrigated paddy ecosystem of Bangladesh: field study of two consecutive rice growing seasons. Plant and Soil 378:239-252.

Baribault, T. W., Kobe, R. K., Finley, A. O. (2012). Tropical tree growth is correlated with soil phosphorus, potassium, and calcium, though not for legumes. Ecology Monographs 82:189-203.

Cacique, I. S., Domiciano, G. P., Moreira, W. R., Rodrigues, F. A., Cruz, M. F. A., Serra, N. S., Catala, A. B. (2013). Effect of root and leaf applications of soluble silicon on blast development in rice. Bragantia 72: 304-309.

Carvalho-Pupatto, J. G., Bull, L. T. and Crusciol, C. A. C. (2004). Soil chemical attributes, root growth and rice yield according to slag application. Pesquisa Agropecuaria Brasileira 39:1213-1218.Cleveland, C. C. and Liptzin, D. (2007). C:N:P stoichiometry in soil: is there a "Redfield ratio" for the microbial biomass? Biogeochemistry 85:235-252.

Datnoff, L. E., Raid, R. N., Snyder, G. H., Jones, D. B. (1991). Effect of calcium silicate on blast and brown spot intensities and yields of rice. Plant Disease 75:729-732.

Deren, C. W. (1997) Changes in nitrogen and phosphorus concentrations of siliconfertilized rice grown on organic soil. Journal of Plant Nutrition 20:765-771.

Elser, J. J., Acharya, K., Kyle, M., Cotner, J., Markow, W., Watts, T., Hobbie, S., Fagan, W., Schade, J., Hood, J. and Sterner, R. (2003). Growth rate- stoichiometry couplings in diverse biota. Ecology Letters 6:936-943.

FAO. (2003). World agricultural towards 2015/2030. An FAO Perspective. FAO, Rome.

Fox, J., Nie, Z. And Byrnes, J. (2013). Sem: Structural Equation Models.

Frattini, M., Morello, L., Breviario, D. (1999). Rice calcium-dependent protein kinase isoforms OsCDPK211 show different responses to light and different expression patterns during seed development. Plant Molecular Biology 41:753-764.

Gu, H. H., Qiu, H., Tian, T., Zhan, S. S., Deng, T. H. B., Chaney, R. L., Wang, S. Z., Tang, Y. T., Morel, J. L. and Qiu, R. L. (2011). Mitigation effects of silicon rich amendments on heavy metal accumulation in rice (Oryza sativa L.) planted on multi-metal contaminated acidic soil. Chemosphere 83:1234-1240.

Guntzer, F., Keller, C., Menunier, J. D. (2012). Benefits of plant silicon for crops: a review. Agronomy for Sustainable Development 32:201-213.

He, Z. L., Alva, A. K., Calvert, D. V., Li, Y. C., Banks, D. J. (1999). Effects of nitrogen 
fertilization of grapefruit trees on soil acidification and nutrient availability in a Riviera fine stand. Plant and Soil 206:11-19.

Hochberg, Y., Benjamini, Y. (1990). More powerful procedures for multiple significance testing. Statistics Medica 9:811-818.

Kim, P. J., Yang, M., Chang, K. W. (2005). Reducing nitrogen fertilization level of rice (Oryza sativa L.) by silicate application in Korean paddy soil. Korean Journal of Soil Science 38:194-201.

Kirwan, M. L. and Guntenspergen, G. R. (2012). Feedbacks between inundation, root production, and shoot growth in a rapidly submerging brackish marsh. Journal of Ecology 100:764-770.

Kobayashi, T., Ryder, D. S., Gordon, G., Shannon, I., Ingleton, T., Carpenter, M. and Jacobs, S. J. (2009). Short-term response of nutrients, carbon and planktonic microbial communities to floodplain wetland inundation. Aquatic Ecology 43:843858.

Lapenis, A.G., Lawrence, G.B., Heim, A., Zheng, C.Y., Shortle, W. (2013). Climate warming shifts carbon allocation from stemwood to roots in calcium-depleted spruce forests. Global Biogeochemical Cycles 27. DOI: 10.1029/2011GB004268.

Lavakush, Yadav, J., Verma, J. P., Jaiswal, D. K., Kumar, A. (2014) Evaluation of PGPR and different concentration of phosphorus level on plant growth, yield and nutrient content of rice (Oryza sativa). Ecological Engineering 62:123-128.

Lee, C. H., Kim, S. Y., Villamil, M. B., Pramanik, P., Hong, C. K. and Kim, P. J. (2012). Different response of silicate fertilizer having electron acceptors on methane emission in rice paddy soil under green manuring. Biology and Fertility of Soils 48:435-442.

Lee, Y. B., Lee, C. H., Hwang, J. Y., Lee, I. B. and Kim, P. J. (2004). Enhancement of phosphate desorption by silicate in soils with salt accumulation. Journal of Plant Nutrition and Soil Science 50:493-499.

Lu, R. K. (1999). Analytical methods of soil agrochemistry. China Agricultural Science and Technology Press, Beijing.

Luo, F. L., Liao, J. F., Wu, L. Y. and Chen, X. L. (2002). Harnessing measures of waterlogged rice field in Fujian Province. Fujian Agriculture Science and Technology 4:26-28.

Meng, H. D., Liu, L. (2000) Stability processing technology and application prospect of steel slag. Steelmaking 25, 74-78.

Montejo, C., Tonini, D., Márquez, M. C. and Astrup, T. F. (2013). Mechanical-biological treatment: Performance and potentials. An LCA of 8 MBT plants including waste characterization. Journal of Environmental Management 128:661-673.

Naples, B.K., Fisk, M.C. (2010). Belowground insights into nutrient limitation in northern hardwood forests. Biogeochemistry 97, 109-121.

Ning, D. F., Song, A. L., Fan, F. L., Li, Z. J. and Liang, Y.C. (2014). Effects of slag-based silicon fertilizer on rice growth and brown-spot resistance. Plos One 9:e102681.

Nishida, M., Sekiya, H. and Yoshida, K. (2013). Status of paddy soils as affected by paddy rice and upland soybean rotation in northeast Japan, with special reference to nitrogen fertility. Soil Science and Plant Nutrition 59:208-217.

Nishikawa, T., Li, K., Inoue, H., Umeda, M., Hirooka, H. and Inamura, T. (2012). Effects of the long-term application of anaerobically-digested cattle manure on growth, yield and nitrogen uptake of paddy rice (Oryza sativa L.), and soil fertility in warmer region of Japan. Plant Production Science 15:284-292.

Rodrigues, F. A., Datnoff, L. E., Korndorfer, G.H., Seebold, K. W., Rush, M. C. (2001). Effect of silicon and host resistance on sheath blight development in rice. Plant 
Disease 85:827-832.

Rodrigues, F. A., Vale, F. X. R., Datnoff, L. E., Prabhu, A. S., Korndorfer, G. H. (2003). Effect of rice growth stages and silicon on sheath blight development. Phytopathology 93:256-261.

Sano, N., Ono, H., Murata, K., Yamada, T., Hirasawa, T., Kanekatsu, M. (2015). Accumulation of long-lived mRNAs associated with germination in embryos during seed development of rice. Journal of Experimental Botany 66:4035-4046

Sardans, J., Rivas-Ubach, A., Peñuelas, J. (2012a). The elemental stoichiometry of aquatic and terrestrial ecosystems and its relationships with organism life style and ecosystem structure and function: a review. Biogeochemistry 111:1-39.

Sardans, J., Rivas-Ubach, A., Peñuelas, J. (2012b). The C:N:P stoichiometry of organisms and ecosystems in a changing world: a review and perspectives. Perspectives in Plant Ecology Evolution and Systematics 14:33-47.

Shariatmadari, H. and Mermut, A.R. (1999). Magnesium and silicon induced phosphate in smectite, playgorskite, and sepiolite-calcite systems. Soil Science Society of America Journal 63:1167-1173.Song, X., Li, L., Zheng, J., Pan, G., Zhang, X., Zheng, J., Hussain, Q., Han, X. and Yu, X. (2012). Sequestration of maize crop straw $\mathrm{C}$ in different soils: role of oxyhydrates in chemical binding and stabilization as recalcitrance. Chemosphere 87:649-654.

Song, A., Ning, D. F., Fan, F. L., Li, Z. J., Provenance-Bowley, M., Liang, Y. C. (2015). The potential for carbon bio-sequestration in China paddy rice (Oryza sativa L.) as impacted by slag-based silicate fertilizer. Scientific Reports 5:17354.

Wang W, Zeng C, Sardans J, Wang C, Zeng D, Peñuelas J. (2016). Amendment with industrial and agricultural wastes reduces surface-water nutrient loss and storage of dissolved greenhouse gases in a subtropical paddy field. Agriculture Ecosystems and Environment 231:296-303.

Wang, W., Sardans, J., Lai, D. Y. F., Wang, C., Zeng, C., Tong, C., Liang, Y. and Peñuelas, J. (2015). Effects of steel slag application on greenhouse gas emissions and crop yield over multiple growing seasons in a subtropical paddy field in China. Field Crops Research 171:146-156.

Wang, W., Sardans, J., Zeng, C., Zhong, C., Li, Y. and Peñuelas, J. (2014). Responses of soil nutrient concentrations and stoichiometry to different human land uses in a subtropical tidal wetland. Geoderma 232:459-470.

Wang, W. Q., Li, P. F., Zeng, C. S. and Tong, C. (2012). Evaluation of silicate iron slag as a potential methane mitigating method. Advanced Materials Research 468:16261630.

Wang, W. Q., Li, P. F., Zeng, C. S., Wang, C. and Lin, F. (2013). Effect of iron slag adding on methane production, oxidation and emission in paddy fields. Acta Ecologica Sinica 33:1578-1583.

Xie, W. and Xie, X. (2003). Cleansing production technology of iron and steel industry in China. Energy for Metallurgical Industry 22:49-53.

Yi, H., Xu, G., Cheng, H., Wang, J., Wan, Y., Chen, H. (2012) An overview of utilization of steel slag. Proc. Enviro. Sci. 16, 791-801.

Zhang, B., Pang, C., Qin, J., Liu, K. and Li, H. (2013). Rice straw incorporation in winter with fertilizer-N application improves soil fertility and reduces global warming potential from a double rice paddy field. Biology and Fertility of Soils 49:10391052.

Zhao, X., Wang, J., Wang, S. and Xing, G. (2014). Successive straw biochar application as a strategy to sequester carbon and improve fertility: A pot experiment with two rice/wheat rotations in paddy soil. Plant and Soil 378:279-294. 
Zhao, N. (2012). Study on the impact of slag on the nutrient dynamics of water-soil-plant system. Fujian Normal University.

492 Zhu, D. F. (2006). System of rice intensification. Beijing: China Agricultural Science and Technology Press. 
Table 1. Soil and plant nutrient concentrations and stoichiometries (mean \pm SE). Significant $(P<0.05)$ values are highlighted in bold type. Different letters among treatments indicate significant differences. $\mathrm{MBC}=$ Soil microbial biomass carbon. $\mathrm{DOC}=$ Soil dissolved organic carbon

\begin{tabular}{|c|c|c|c|c|c|c|}
\hline & \multirow{2}{*}{ Variable } & \multicolumn{4}{|c|}{ Rate of steel slag amendment } & \multirow{2}{*}{ Treatments } \\
\hline & & $0 \mathrm{Mg} \mathrm{ha}^{-1}$ & $2 \mathrm{Mg} \mathrm{ha}^{-1}$ & $4 \mathrm{Mg} \mathrm{ha}^{-1}$ & $8 \mathrm{Mg} \mathrm{ha}^{-1}$ & \\
\hline \multirow{11}{*}{$\overline{\bar{\delta}}$} & MBC concentration $\left(\mathrm{mg} \mathrm{kg}^{-1}\right)$ & $609 \pm 64$ & $719 \pm 39$ & $670 \pm 41$ & $624 \pm 45$ & $F=1.071 ; P=0.366$ \\
\hline & DOC concentration $\left(\mathrm{mg} \mathrm{kg}^{-1}\right)$ & $240 \pm 35$ & $277 \pm 33$ & $255 \pm 32$ & $263 \pm 29$ & $F=0.227 ; P=0.878$ \\
\hline & Available-N concentration ( $\mathrm{mg} \mathrm{kg}^{-1}$ ) & $7.90 \pm 1.31 \mathrm{~b}$ & $10.9 \pm 1.7 \mathrm{ab}$ & $16.6 \pm 3.6 \mathrm{a}$ & $8.96 \pm 1.59 b$ & $F=3.046 ; P=0.033$ \\
\hline & Available-P concentration ( $\mathrm{mg} \mathrm{kg}^{-1}$ ) & $3.13 \pm 0.34 b$ & $4.57 \pm 0.56 \mathrm{ab}$ & $5.06 \pm 0.56 \mathrm{a}$ & $5.54 \pm 0.69 \mathrm{a}$ & $F=3.575 ; P=0.018$ \\
\hline & Available-K concentration $\left(\mathrm{mg} \mathrm{kg}^{-1}\right)$ & $141 \pm 12$ & $137 \pm 10$ & $142 \pm 11$ & $141 \pm 9$ & $F=0.046 ; P=0.987$ \\
\hline & Available-Si concentration $\left(\mathrm{mg} \mathrm{kg}^{-1}\right)$ & $330 \pm 10 \mathrm{c}$ & $921 \pm 35 b$ & $1093 \pm 93 \mathrm{ab}$ & $1295 \pm 143 a$ & $F=22.893 ; P<0.001$ \\
\hline & Available-Ca concentration ( $\mathrm{cmol} \mathrm{kg}^{1}$ ) & $0.033 \pm 0.002 \mathrm{a}$ & $0.033 \pm 0.002 \mathrm{a}$ & $0.046 \pm 0.003 b$ & $0.047 \pm 0.004 b$ & $F=8.231 ; P<0.001$ \\
\hline & Available-Mg concentration ( $\mathrm{cmol} \mathrm{kg}^{1}$ ) & $0.046 \pm 0.005$ & $0.051 \pm 0.006$ & $0.049 \pm 0.005$ & $0.039 \pm 0.002$ & $F=1.417 ; P=0.244$ \\
\hline & DOC:available-N ratio & $30.4 \pm 7.3$ & $25.4 \pm 3.9$ & $15.4 \pm 5.5$ & $29.4 \pm 4.8$ & $F=0.842 ; P=0.475$ \\
\hline & DOC:available-P ratio & $76.7 \pm 11.5 \mathrm{a}$ & $60.6 \pm 7.9 \mathrm{ab}$ & $50.4 \pm 3.6 b$ & $47.5 \pm 3.7 b$ & $F=3.320 ; P=0.024$ \\
\hline & Available N:available-P ratio & $2.52 \pm 0.14 \mathrm{ab}$ & $2.39 \pm 0.14 \mathrm{ab}$ & $3.28 \pm 0.33 \mathrm{a}$ & $1.62 \pm 0.13 \mathrm{~b}$ & $F=2.306 ; P=0.083$ \\
\hline \multirow{18}{*}{$\frac{\vec{\Xi}}{\stackrel{\vec{\Xi}}{a}}$} & Foliar $\mathrm{C}$ concentration $\left(\mathrm{mg} \mathrm{g}^{-1}\right)$ & $411 \pm 3 a$ & $396 \pm 4 b$ & $398 \pm 5 b$ & $391 \pm 5 b$ & $F=4.294 ; P=0.007$ \\
\hline & Foliar $\mathrm{N}$ concentration $\left(\mathrm{mg} \mathrm{g}^{-1}\right)$ & $32.3 \pm 2.9$ & $33.3 \pm 3.0$ & $33.2 \pm 3.3$ & $35.0 \pm 3.2$ & $F=0.127 ; P=0.994$ \\
\hline & Foliar $\mathrm{P}$ concentration $\left(\mathrm{mg} \mathrm{g}^{-1}\right)$ & $1.16 \pm 0.22$ & $1.33 \pm 0.27$ & $1.36 \pm 0.26$ & $1.44 \pm 0.26$ & $F=0.212 ; P=0.888$ \\
\hline & Foliar C: $\mathrm{N}$ ratio & $12.7 \pm 0.8$ & $11.9 \pm 0.8$ & $12.0 \pm 0.7$ & $11.2 \pm 0.6$ & $F=0.432 ; P=0.731$ \\
\hline & Foliar C:P ratio & $354 \pm 40$ & $298 \pm 38$ & $293 \pm 37$ & $272 \pm 34$ & $F=0.731 ; P=0.536$ \\
\hline & Foliar N:P ratio & $27.8 \pm 4.7$ & $25.0 \pm 5.2$ & $24.4 \pm 5.0$ & $24.3 \pm 4.6$ & $F=0.048 ; P=0.986$ \\
\hline & Stem $\mathrm{C}$ concentration $\left(\mathrm{mg} \mathrm{g}^{-1}\right)$ & $384 \pm 4 a$ & $374 \pm 4 \mathrm{ab}$ & $375 \pm 4 \mathrm{ab}$ & $372 \pm 4 b$ & $F=1.989 ; P=0.122$ \\
\hline & Stem $\mathrm{N}$ concentration $\left(\mathrm{mg} \mathrm{g}^{-1}\right)$ & $15.5 \pm 2.3$ & $16.6 \pm 2.3$ & $17.4 \pm 2.3$ & $17.6 \pm 2.3$ & $F=0.176 ; P=0.912$ \\
\hline & Stem $\mathrm{P}$ concentration $\left(\mathrm{mg} \mathrm{g}^{-1}\right)$ & $1.43 \pm 0.24$ & $1.57 \pm 0.27$ & $1.58 \pm 0.27$ & $1.76 \pm 0.28$ & $F=0.261 ; P=0.853$ \\
\hline & Stem $\mathrm{C}: \mathrm{N}$ ratio & $24.8 \pm 4.1$ & $22.5 \pm 3.1$ & $21.6 \pm 2.3$ & $21.1 \pm 2.4$ & $F=1.154 ; P=0.333$ \\
\hline & Stem C:P ratio & $269 \pm 35$ & $238 \pm 33$ & $237 \pm 32$ & $211 \pm 32$ & $F=0.396 ; P=0.756$ \\
\hline & Stem N:P ratio & $10.8 \pm 2.7$ & $10.6 \pm 2.7$ & $11.0 \pm 2.6$ & $10.0 \pm 2.6$ & $F=0.009 ; P=0.999$ \\
\hline & Root $\mathrm{C}$ concentration $\left(\mathrm{mg} \mathrm{g}^{-1}\right)$ & $340 \pm 9$ & $340 \pm 8$ & $336 \pm 9$ & $347 \pm 11$ & $F=0.257 ; P=0.856$ \\
\hline & Root $\mathrm{N}$ concentration $\left(\mathrm{mg} \mathrm{g}^{-1}\right)$ & $11.3 \pm 1.1$ & $9.70 \pm 1.09$ & $10.2 \pm 1.0$ & $9.83 \pm 0.99$ & $F=0.474 ; P=0.701$ \\
\hline & Root $\mathrm{P}$ concentration $\left(\mathrm{mg} \mathrm{g}^{-1}\right)$ & $3.39 \pm 0.43$ & $3.12 \pm 0.40$ & $2.82 \pm 0.47$ & $3.33 \pm 0.44$ & $F=0.344 ; P=0.793$ \\
\hline & Root $\mathrm{C}: \mathrm{N}$ ratio & $30.1 \pm 2.4$ & $35.1 \pm 2.6$ & $32.9 \pm 2.3$ & $35.3 \pm 2.8$ & $F=0.522 ; P=0.669$ \\
\hline & Root $\mathrm{C}: \mathrm{P}$ ratio & $100 \pm 23$ & $109 \pm 21$ & $119 \pm 24$ & $104 \pm 23$ & $F=0.427 ; P=0.734$ \\
\hline & Root N:P ratio & $3.33 \pm 1.21$ & $3.11 \pm 1.19$ & $3.62 \pm 1.40$ & $2.95 \pm 1.11$ & $F=0.495 ; P=0.687$ \\
\hline
\end{tabular}


Table 2. Pearson correlations among rice yield and biomasses with soil and plant nutrient concentrations and ratios. Significant correlations after applying the Benjamini \& Hoghberg correction of false discovery rate $(R> \pm 0.642, P<0.0025)$ are highlighted in bold type $(\mathrm{n}=12)$.

\begin{tabular}{|c|c|c|c|c|}
\hline Variable & Yield & Shoot biomass & Root biomass & Total biomass \\
\hline \multicolumn{5}{|l|}{ Soil } \\
\hline MBC concentration & 0.047 & -0.142 & -0.161 & 0.002 \\
\hline DOC concentration & 0.431 & 0.079 & 0.398 & 0.375 \\
\hline Available-N concentration & 0.337 & 0.552 & -0.089 & 0.350 \\
\hline Available-P concentration & $0.972^{*}$ & $0.837^{*}$ & $0.838^{*}$ & $0.959^{*}$ \\
\hline Available-K concentration & 0.260 & 0.605 & 0.158 & 0.319 \\
\hline Available-Si concentration & $0.968^{*}$ & $0.824^{*}$ & $0.839^{*}$ & $0.954^{*}$ \\
\hline Available-Ca concentration & $0.902^{*}$ & $0.997^{*}$ & $0.746 *$ & $0.927^{*}$ \\
\hline Available-Mg concentration & -0.516 & -0.470 & $-0.764^{*}$ & -0.533 \\
\hline DOC:available-N ratio & -0.530 & -0.358 & -0.279 & -0.495 \\
\hline DOC:available-P ratio & $-0.943^{*}$ & $-0.919^{*}$ & $-0.719^{*}$ & $-0.944^{*}$ \\
\hline Available-N:available-P ratio & -0.291 & 0.010 & $-0.660^{*}$ & -0.266 \\
\hline \multicolumn{5}{|l|}{ Plant } \\
\hline Foliar $\mathrm{C}$ concentration & $-0.896^{*}$ & $-0.652^{*}$ & $-0.835^{*}$ & $-0.867^{*}$ \\
\hline Foliar $\mathrm{N}$ concentration & $0.906 *$ & $0.687^{*}$ & $0.993^{*}$ & $0.890^{*}$ \\
\hline Foliar $\mathrm{P}$ concentration & $0.966^{*}$ & $0.794^{*}$ & $0.871^{*}$ & $0.949^{*}$ \\
\hline Foliar C:N ratio & $-0.948^{* *}$ & $-0.735^{*}$ & $-0.966^{*}$ & $-0.930^{*}$ \\
\hline Foliar C:P ratio & $-0.976^{*}$ & $-0.802^{*}$ & $-0.959^{*}$ & $-0.963^{* *}$ \\
\hline Foliar $\mathrm{N}: \mathrm{P}$ ratio & $-0.879^{*}$ & $-0.825^{*}$ & $-0.946^{*}$ & $-0.891^{*}$ \\
\hline Stem $C$ concentration & $-0.874^{*}$ & $-0.643^{*}$ & $-0.770^{*}$ & $-0.845^{*}$ \\
\hline Stem $\mathrm{N}$ concentration & $0.975^{*}$ & $0.905^{*}$ & $0.800^{*}$ & $0.971^{*}$ \\
\hline Stem $P$ concentration & $0.950^{*}$ & $0.750^{*}$ & $0.979^{*}$ & $0.935^{*}$ \\
\hline Stem $\mathrm{C}: \mathrm{N}$ ratio & $-0.937^{*}$ & $-0.853^{*}$ & $-0.728^{*}$ & $-0.927^{*}$ \\
\hline Stem C:P ratio & $-0.965^{*}$ & $-0.779^{*}$ & $-0.971^{*}$ & $-0.951^{*}$ \\
\hline Stem N:P ratio & $-0.797^{*}$ & -0.507 & $-0.952^{*}$ & $-0.771^{*}$ \\
\hline Root $\mathrm{C}$ concentration & 0.443 & 0.189 & $0.778^{*}$ & 0.427 \\
\hline Root $\mathrm{N}$ concentration & $-0.727^{*}$ & -0.440 & -0.637 & $-0.685^{*}$ \\
\hline Root $\mathrm{P}$ concentration & -0.288 & -0.429 & 0.134 & -0.293 \\
\hline Root C:N ratio & $0.700^{*}$ & 0.358 & $0.709^{*}$ & $0.654^{*}$ \\
\hline Root $\mathrm{C}: \mathrm{P}$ ratio & 0.384 & $0.699^{*}$ & 0.017 & 0.425 \\
\hline Root N:P ratio & 0.133 & $0.489^{*}$ & -0.244 & 0.175 \\
\hline
\end{tabular}

*, significant correlation at $P<0.05$; **, significant correlation at $P<0.0022 \mathrm{R}= \pm 0.642$ (after applying the Benjamini \& Hoghberg correction of false discovery rate).

$\mathrm{MBC}=$ Soil microbial biomass carbon $\mathrm{DOC}=$ Soil dissolved organic carbon 
Table 3. Plant nutrient contents and stoichiometries in the various treatments (mean $\pm \mathrm{SE}$ ).

\begin{tabular}{|l|l|l|l|l|}
\hline \multirow{2}{*}{ Variable } & \multicolumn{4}{|c|}{ Steel slag amendment rate } \\
\cline { 2 - 5 } & $0 \mathrm{Mg} \mathrm{ha}^{-1}$ & $2 \mathrm{Mg} \mathrm{ha}^{-1}$ & $4 \mathrm{Mg} \mathrm{ha}^{-1}$ & $8 \mathrm{Mg} \mathrm{ha}^{-1}$ \\
\hline Above-/belowground C ratio & $7.12 \pm 0.28 \mathrm{a}$ & $6.52 \pm 0.15 \mathrm{~b}$ & $6.46 \pm 0.52 \mathrm{~b}$ & $6.49 \pm 0.12 \mathrm{~b}$ \\
\hline Above-/belowground N ratio & $11.7 \pm 0.3 \mathrm{~b}$ & $15.9 \pm 2.0 \mathrm{a}$ & $12.1 \pm 0.2 \mathrm{~b}$ & $12.8 \pm 0.2 \mathrm{ab}$ \\
\hline Above-/belowground P ratio & $2.32 \pm 0.07 \mathrm{~b}$ & $2.56 \pm 0.07 \mathrm{ab}$ & $2.94 \pm 0.03 \mathrm{a}$ & $2.46 \pm 0.07 \mathrm{~b}$ \\
\hline Total plant C content $\left(\mathrm{kg} \mathrm{ha}^{-1}\right)$ & $6539 \pm 112$ & $6462 \pm 181$ & $6710 \pm 142$ & $6820 \pm 157$ \\
\hline Total plant N content $\left(\mathrm{kg} \mathrm{ha}^{-1}\right)$ & $169 \pm 5 \mathrm{c}$ & $187 \pm 5 \mathrm{ab}$ & $178 \pm 6 \mathrm{bc}$ & $198 \pm 5 \mathrm{a}$ \\
\hline Total plant P content $\left(\mathrm{kg} \mathrm{ha}^{-1}\right)$ & $35.8 \pm 1.9 \mathrm{ab}$ & $34.4 \pm 0.8 \mathrm{~b}$ & $34.3 \pm 1.0 \mathrm{~b}$ & $38.9 \pm 1.1 \mathrm{a}$ \\
\hline Total plant C:N content & $38.7 \pm 0.2 \mathrm{~b}$ & $34.6 \pm 0.3 \mathrm{c}$ & $37.7 \pm 0.4 \mathrm{a}$ & $34.4 \pm 0.4 \mathrm{c}$ \\
\hline Total plant C:P content & $183 \pm 9 \mathrm{ab}$ & $188 \pm 4 \mathrm{ab}$ & $196 \pm 1 \mathrm{a}$ & $175 \pm 4 \mathrm{~b}$ \\
\hline Total plant N:P content & $4.72 \pm 0.09$ & $5.44 \pm 0.1$ & $5.19 \pm 0.12$ & $5.09 \pm 0.15$ \\
\hline
\end{tabular}

Different letters among treatments indicate significant differences $(P<0.05)$. 


\section{Figure legends}

Figure 1. Biplots of the standardized canonical discriminate function coefficients for the first two roots representing the soil and plant variables as independent variables and the various grouping dependent factors corresponding to the levels of steel slag amendment $\left(0,2,4\right.$, and $\left.8 \mathrm{Mg} \mathrm{ha}^{-1}\right)$. Ca avai, soil Ca availability; $\mathrm{Si}_{\text {avai, }}$, soil $\mathrm{Si}$ availability; $\mathrm{K}_{\text {avai, }}$, soil $\mathrm{K}$ availability; $\mathrm{Mg}_{\text {avai, }}$, soil $\mathrm{Mg}$ availability; $\mathrm{N}_{\text {avai }}$, soil $\mathrm{N}$ availability; $\mathrm{P}_{\text {avai, }}$, soil $\mathrm{P}$ availability; DOC, dissolved organic C; DOC: $\mathrm{N}_{\text {avai }}$, DOC:soil available-N ratio; DOC: $\mathrm{P}_{\text {avai, }}$ DOC:soil available-P ratio; $\mathrm{N}_{\text {avai }}$; $\mathrm{P}_{\text {avai, }}$, soil available- $\mathrm{N}$ :soil available-P ratio; $\mathrm{LN}$, foliar $\mathrm{N}$ concentration; LP, foliar P concentration; LC, foliar C concentration; $\mathrm{SN}$, stem $\mathrm{N}$ concentration; SP, stem P concentration; SC, stem $\mathrm{C}$ concentration; $\mathrm{RN}$, root $\mathrm{N}$ concentration; RP, root $\mathrm{P}$ concentration; $\mathrm{RC}$, root $\mathrm{C}$ concentration; $\mathrm{LC}: \mathrm{N}$, foliar $\mathrm{C}: \mathrm{N}$ concentration ratio; LC:P, foliar $\mathrm{C}: \mathrm{P}$ concentration ratio; LN:P, foliar $\mathrm{N}: \mathrm{P}$ concentration ratio; $\mathrm{SC}: \mathrm{N}$, stem $\mathrm{C}: \mathrm{N}$ concentration ratio; $\mathrm{SC}: \mathrm{P}$, stem $\mathrm{C}: \mathrm{P}$ concentration ratio; $\mathrm{SN}: \mathrm{P}$, stem $\mathrm{N}: \mathrm{P}$ concentration ratio; $\mathrm{RC}: \mathrm{N}$, root $\mathrm{C}: \mathrm{N}$ concentration ratio; $\mathrm{RC}: \mathrm{P}$, root $\mathrm{C}: \mathrm{P}$ concentration ratio; $\mathrm{RN}: \mathrm{P}$, root $\mathrm{N}: \mathrm{P}$ concentration ratio; $\mathrm{MBC}$, soil microbial $\mathrm{C}$; $\mathrm{RC}$, rice yield; $\mathrm{LB}$, foliar biomass; SB, stem biomass; RB, root biomass; TB, total biomass.

Figure 2. Diagrams of the structural equation models that best explained the maximum variance of rice yield with steel slag application and soil P, Si and $\mathrm{Ca}$ availability as endogenous variables. Blue and red arrows indicate negative and positive relationships, respectively. 

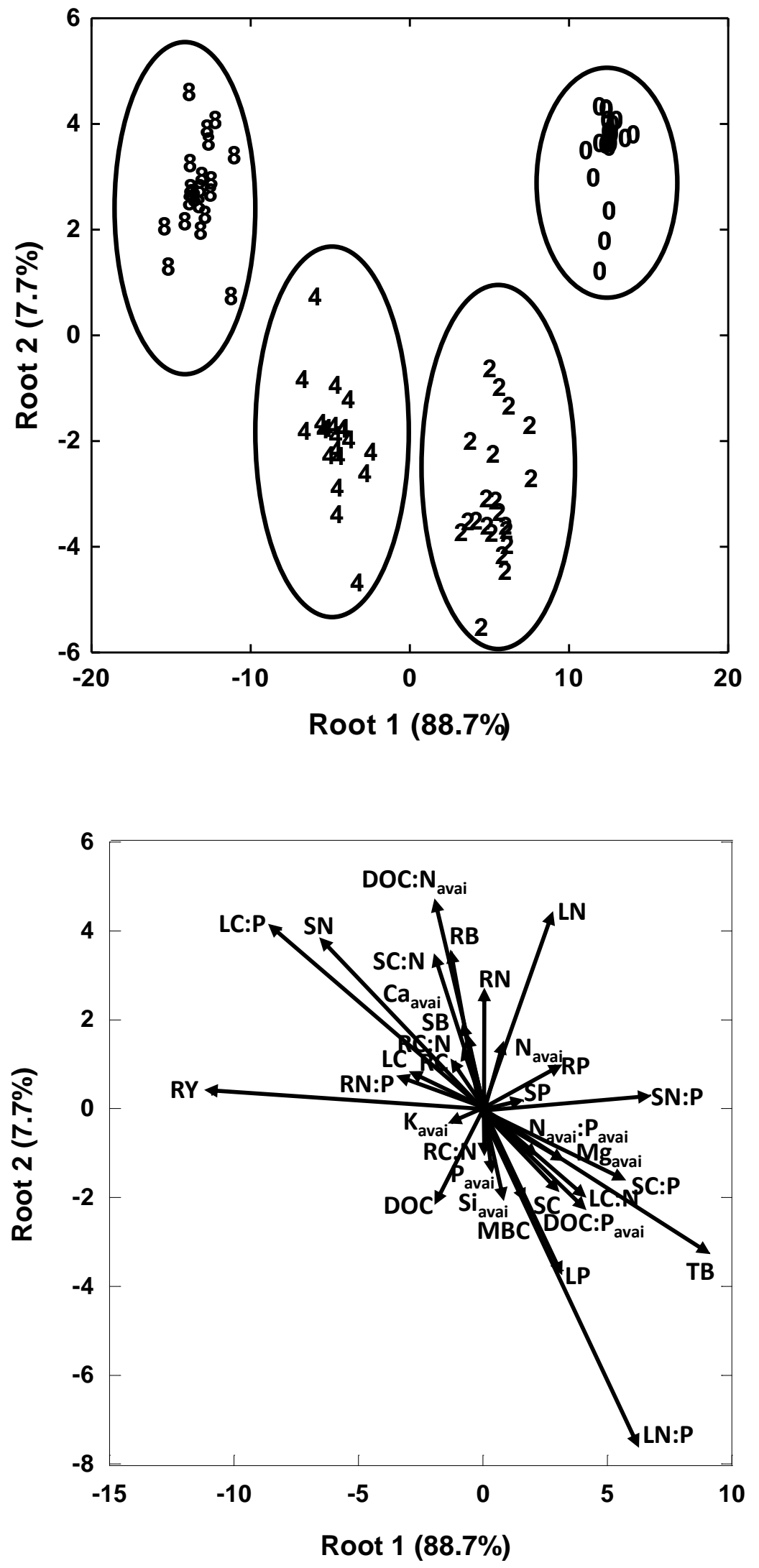

Figure 1 

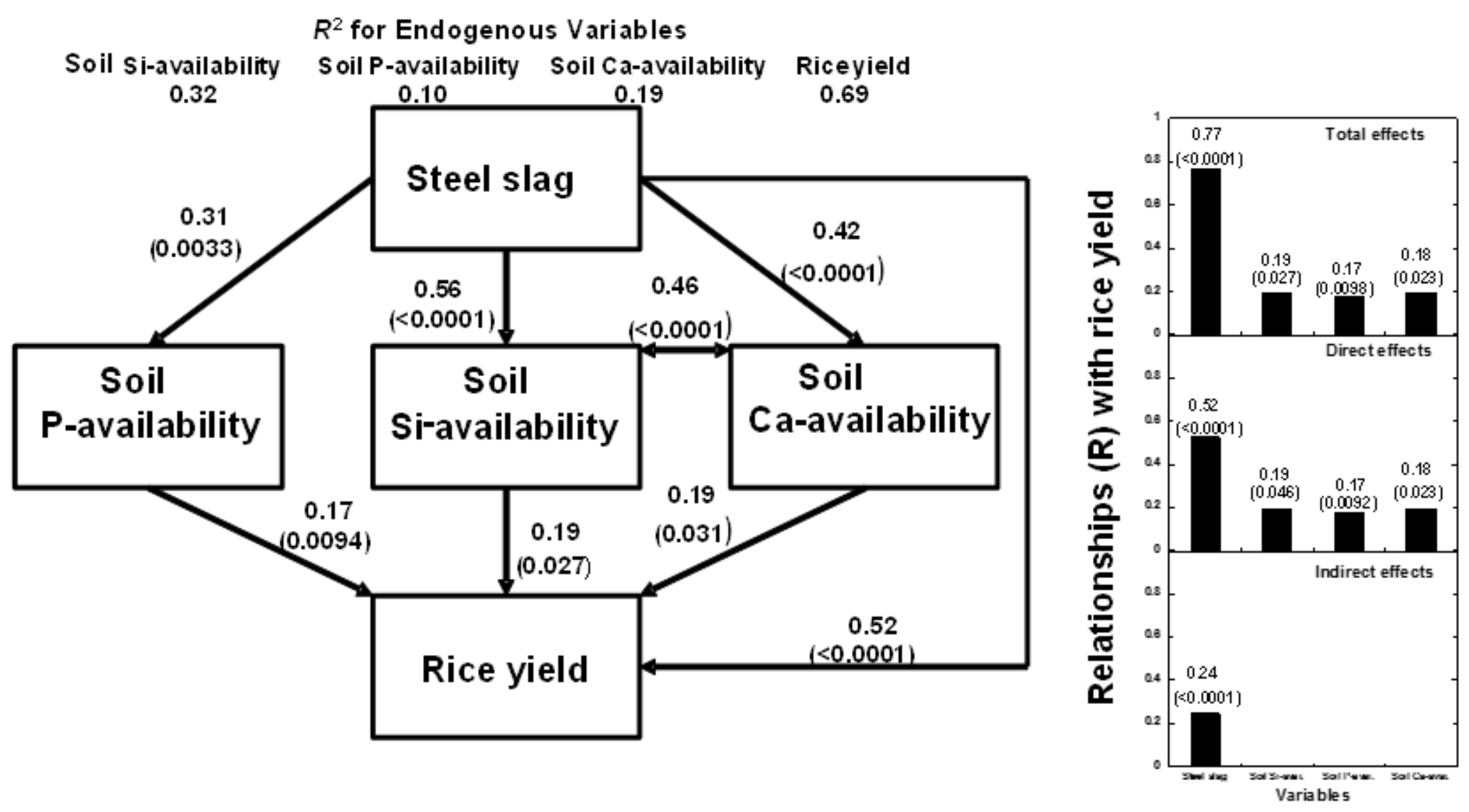

Figure 2 
Supplementary material 
Table S1. Pearson correlations among soil and plant nutrient concentrations and ratios. Significant correlations after applying the Benjamini \& Hoghberg correction of false discovery rate $(R> \pm 0.302, P<0.008)$ are highlighted in bold type $(\mathrm{n}=84)$.

\begin{tabular}{|c|c|c|c|c|c|c|}
\hline Variable & DOC & $\begin{array}{l}\text { Available-N } \\
\text { concentration }\end{array}$ & $\begin{array}{l}\text { Available-P } \\
\text { concentration }\end{array}$ & $\begin{array}{l}\text { DOC:available-N } \\
\text { ratio }\end{array}$ & DOC:available-P ratio & Available-N:available-P ratio \\
\hline Foliar $\mathrm{C}$ concentration & 0.062 & $\mathbf{0 . 4 8 5}^{*}$ & 0.238 & -0.164 & -0.211 & $0.399^{*}$ \\
\hline Foliar $\mathrm{N}$ concentration & -0.217 & $0.545^{*}$ & $0.823^{*}$ & $-0.511^{*}$ & $-0.515^{*}$ & 0.197 \\
\hline Foliar P concentration & $0.638^{*}$ & $-0.490^{*}$ & -0.243 & $0.768^{*}$ & $0.325^{*}$ & $-0.485^{*}$ \\
\hline Foliar C:N ratio & 0.061 & $-0.500^{*}$ & $-0.698^{*}$ & $0.320^{*}$ & $0.421^{*}$ & -0.181 \\
\hline Foliar C:P ratio & $-0.741^{*}$ & $0.609^{*}$ & $0.424^{*}$ & $-0.836^{*}$ & $-0.542^{*}$ & $0.498^{*}$ \\
\hline Foliar N:P ratio & $-0.602^{*}$ & $0.643^{*}$ & $0.765^{*}$ & $-0.782^{*}$ & $-0.616^{*}$ & $0.305^{*}$ \\
\hline Stem $\mathrm{C}$ concentration & 0.246 & $0.311^{*}$ & 0.007 & 0.081 & -0.106 & 0.292 \\
\hline Stem $\mathrm{N}$ concentration & $-0.374^{*}$ & $0.670^{*}$ & $0.813^{*}$ & $-0.620^{*}$ & $-0.624^{*}$ & $0.328^{*}$ \\
\hline Stem $\mathrm{P}$ concentration & $0.645^{*}$ & $-0.592^{*}$ & $-0.301^{*}$ & $0.847^{*}$ & $0.446^{*}$ & $-0.552^{*}$ \\
\hline Stem C:N ratio & 0.116 & $-0.552^{*}$ & $-0.688^{*}$ & $\mathbf{0 . 3 5 3}^{*}$ & $0.543^{*}$ & -0.213 \\
\hline Stem C:P ratio & $-0.609^{*}$ & $0.708^{* *}$ & 0.289 & $-0.809^{*}$ & $-0.555^{*}$ & $0.657^{*}$ \\
\hline Stem N:P ratio & $-0.554^{*}$ & $0.791^{* * *}$ & $0.605^{*}$ & $-0.790^{*}$ & $-0.636^{*}$ & $0.577^{*}$ \\
\hline Root $\mathrm{C}$ concentration & $0.482^{*}$ & -0.109 & $-0.565^{*}$ & $0.448^{*}$ & $0.365^{*}$ & 0.091 \\
\hline
\end{tabular}




\begin{tabular}{|c|c|c|c|c|c|c|}
\hline Root $\mathrm{N}$ concentration & $-0.557^{*}$ & $0.712^{*}$ & $0.573^{*}$ & $-0.670^{*}$ & $-0.622^{*}$ & $0.492^{*}$ \\
\hline Root $\mathrm{P}$ concentration & $0.549^{*}$ & $-0.736^{*}$ & $-0.540^{*}$ & $0.746^{*}$ & $0.635^{*}$ & $-0.510^{*}$ \\
\hline Root $\mathrm{C}: \mathrm{N}$ ratio & $0.458^{*}$ & $-0.600^{*}$ & $-0.599^{*}$ & $0.616^{*}$ & $0.606^{*}$ & $-0.364 *$ \\
\hline Root C:P ratio & $-0.516^{*}$ & $0.767^{*}$ & $0.349^{*}$ & $-0.622^{*}$ & $-0.523^{*}$ & $0.616^{*}$ \\
\hline Root N:P ratio & $-0.581^{*}$ & $0.755^{*}$ & $0.433^{*}$ & $-0.634^{*}$ & $-0.553^{*}$ & $0.568^{*}$ \\
\hline
\end{tabular}

* significant correlation at $P<0.008$ (after applying the Benjamini \& Hoghberg correction of false discovery rate).

DOC $=$ Soil dissolved organic carbon 
Table S2. Test statistics for squared Mahalanobis distances among treatments with different levels of steel slag amendment with soil $\mathrm{Ca}, \mathrm{Si}, \mathrm{K}, \mathrm{Mg}, \mathrm{N}$, and $\mathrm{P}$ availabilities; $\mathrm{DOC}$ and $\mathrm{MBC}$ concentrations; the ratios of DOC:available N, DOC:available $P$, and available N:available $P$; foliar, stem, and root $\mathrm{N}, \mathrm{P}$, and $\mathrm{C}$ concentrations and $\mathrm{C}: \mathrm{N}, \mathrm{C}: \mathrm{P}$, and $\mathrm{N}: \mathrm{P}$ concentration ratios; foliar, stem, root, and total biomasses; and rice yield as variables.

\begin{tabular}{|c|c|c|c|}
\hline \multirow[b]{2}{*}{ Mg steel slag ha ${ }^{-1}$} & \multicolumn{3}{|c|}{ Mg steel slag ha-1 } \\
\hline & 2 & 4 & 8 \\
\hline \multirow{3}{*}{0} & $S M=102$ & $S M=327$ & $S M=663$ \\
\hline & $F=19.5$ & $F=62.4$ & $F=126$ \\
\hline & $P<0.0001$ & $P<0.0001$ & $P<0.0001$ \\
\hline \multirow{3}{*}{2} & & $S M=127$ & $S M=102$ \\
\hline & & $F=24.3$ & $F=380$ \\
\hline & & $P<0.0001$ & $P<0.0001$ \\
\hline \multirow{3}{*}{4} & & & $S M=102$ \\
\hline & & & $F=113$ \\
\hline & & & $P<0.0001$ \\
\hline
\end{tabular}

$\mathrm{SM}=$ Squared Mahalanobis distances. 
Table S3. Main effects of the variables in the GDA analysis. Statistics (Wilks' $\lambda$ and $P$ ) of the discriminant functional analysis among treatments with soil $\mathrm{Ca}, \mathrm{Si}, \mathrm{K}, \mathrm{Mg}, \mathrm{N}$, and $\mathrm{P}$ availabilities; DOC and MBC concentrations; the ratios of DOC:available N, DOC:available $P$, and available $\mathrm{N}$ :available $\mathrm{P}$; foliar, stem, and root $\mathrm{N}, \mathrm{P}$, and $\mathrm{C}$ concentrations and $\mathrm{C}: \mathrm{N}, \mathrm{C}: \mathrm{P}$, and $\mathrm{N}: \mathrm{P}$ concentration ratios; foliar, stem, root, and total biomasses; and rice yield as variables. Significant effects of a variable in the model are highlighted in bold type $(P<0.05)$.

\begin{tabular}{|l|l|l|}
\hline Independent variable & Wilks' $\lambda$ & $P$ \\
\hline MBC concentration & 0.646 & $<\mathbf{0 . 0 0 0 1}$ \\
\hline DOC concentration & 0.830 & $\mathbf{0 . 0 2 8}$ \\
\hline Available-N concentration & 0.816 & $\mathbf{0 . 0 1 9}$ \\
\hline Available-P concentration & 0.832 & $\mathbf{0 . 0 3 4}$ \\
\hline Available-K concentration & 0.962 & 0.60 \\
\hline Available-Si concentration & 0.631 & $<\mathbf{0 . 0 0 0 1}$ \\
\hline Available-Ca concentration & 0.595 & $<\mathbf{0 . 0 0 0 1}$ \\
\hline Available-Mg concentration & 0.451 & $<\mathbf{0 . 0 0 0 1}$ \\
\hline DOC:available-N ratio & 0.594 & $<\mathbf{0 . 0 0 0 1}$ \\
\hline DOC:available-P ratio & 0.525 & $<\mathbf{0 . 0 0 0 1}$ \\
\hline Available-N:available-P ratio & 0.851 & $\mathbf{0 . 0 5 0}$ \\
\hline Foliar C concentration & 0.656 & $\mathbf{0 . 0 0 0 1 4}$ \\
\hline Foliar N concentration & 0.826 & $\mathbf{0 . 0 2 6}$ \\
\hline Foliar P concentration & 0.765 & $\mathbf{0 . 0 0 4 6}$ \\
\hline Stem C concentration & 0.718 & $\mathbf{0 . 0 0 1 1}$ \\
\hline Stem N concentration & 0.867 & 0.074 \\
\hline Stem P concentration & 0.973 & 0.73 \\
\hline Root C concentration & 0.682 & $\mathbf{0 . 0 0 0 3 4}$ \\
\hline Root N concentration & 0.875 & 0.091 \\
\hline Root P concentration & 0.791 & $\mathbf{0 . 0 0 9 8}$ \\
\hline Foliar C:N ratio & 0.946 & 0.44 \\
\hline Foliar C:P ratio & 0.769 & $\mathbf{0 . 0 0 5 2}$ \\
\hline Foliar N:P ratio & 0.737 & $\mathbf{0 . 0 0 2 0}$ \\
\hline Stem C:N ratio & 0.681 & $\mathbf{0 . 0 0 0 3 3}$ \\
\hline Stem C:P ratio & 0.851 & $\mathbf{0 . 0 4 9}$ \\
\hline Stem N:P ratio & 0.891 & 0.13 \\
\hline Root C:N ratio & 0.949 & 0.47 \\
\hline Root C:P ratio & 0.828 & $\mathbf{0 . 0 2 7}$ \\
\hline Root N:P ratio & 0.852 & 0.051 \\
\hline Rice yield & 0.180 & $<\mathbf{0 . 0 0 0 1}$ \\
\hline Shoot biomass & 0.775 & $\mathbf{0 . 0 0 6 2}$ \\
\hline Root biomass & $\mathbf{0 . 0 0 0 1 3}$ \\
\hline Total biomass & $<\mathbf{0 . 0 0 0 1}$ \\
\hline
\end{tabular}




\section{Figure legends}

Figure S1. The location of the study area and sampling sites $(\boldsymbol{\Delta})$ in Fujian Province, southeastern China.

Figure S2. Concentrations of MBC (A), DOC (B), available N (C), available P (D), available $\mathrm{K}(\mathrm{E})$, available $\mathrm{Si}(\mathrm{F})$, available $\mathrm{Ca}(\mathrm{G})$, and available $\mathrm{Mg}(\mathrm{H})$ during the growing season in the soils of the control and various treatments of steel slag application. Different letters indicate significant differences between treatments $(P<0.05)$.

Figure S3. Ratios of soil DOC:available N (A), soil DOC:available P (B), and soil available N:available $\mathrm{P}(\mathrm{C})$ during the growing season in the soils of control and the various treatments of steel slag application. Different letters indicate significant differences between treatments $(P<0.05)$.

Figure S4. Concentrations of foliar C (A), foliar N (B), foliar P (C), stem C (D), stem N $(\mathrm{E})$, stem $\mathrm{P}(\mathrm{F})$, root $\mathrm{C}(\mathrm{G})$, root $\mathrm{N}(\mathrm{H})$, and root $\mathrm{P}(\mathrm{I})$ during the growing season in control and the various treatments of steel slag application. Different letters indicate significant differences between treatments $(P<0.05)$.

Figure S5. Foliar C:N (A), foliar C:P (B), foliar N:P (C), stem C:N (D), stem C:P (E), stem $\mathrm{N}: \mathrm{P}(\mathrm{F})$, root $\mathrm{C}: \mathrm{N}(\mathrm{G})$, root $\mathrm{C}: \mathrm{P}(\mathrm{H})$, and root $\mathrm{N}: \mathrm{P}(\mathrm{I})$ ratios during the growing season in the plant organs from control and the various treatments of steel slag application. Different letters indicate significant differences between treatments $(P<0.05)$. 


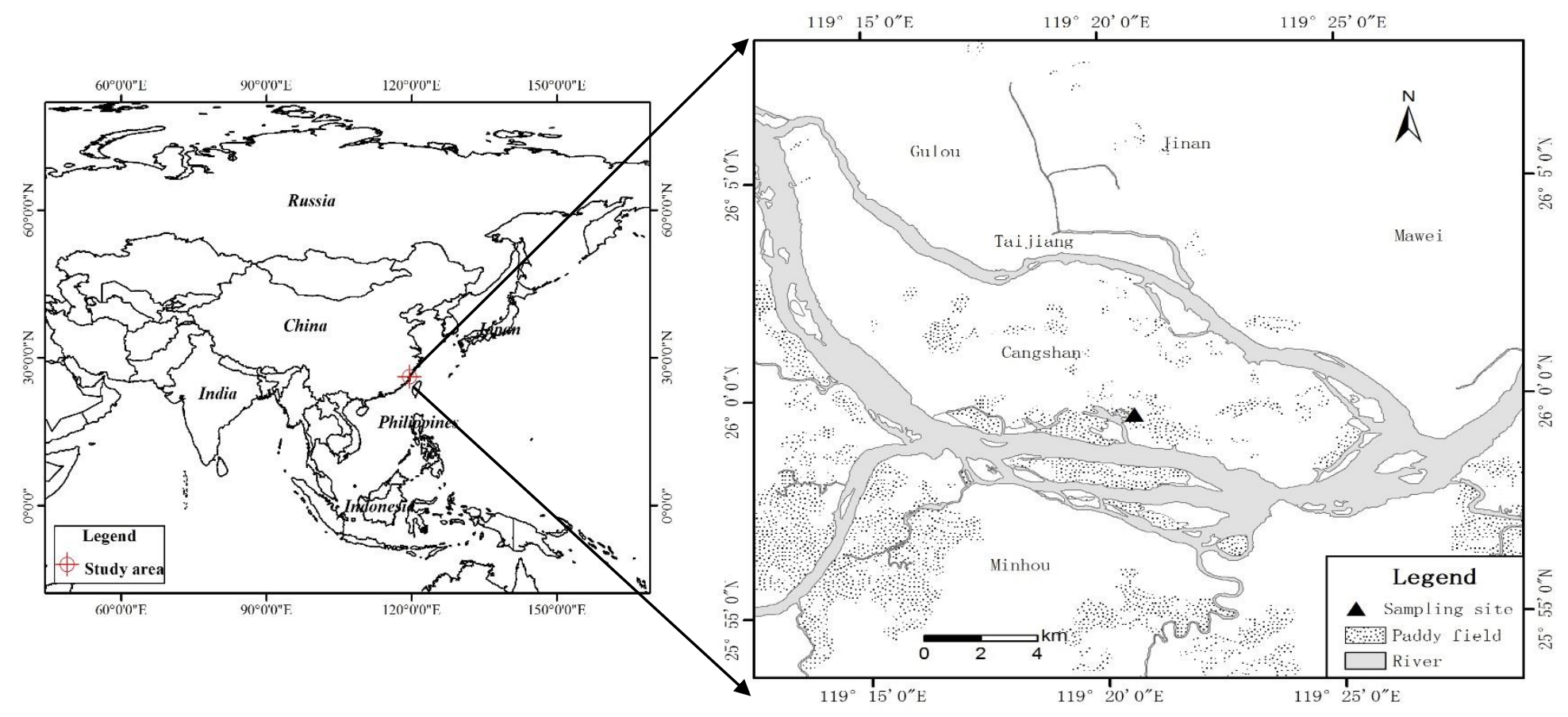

Figure S1 

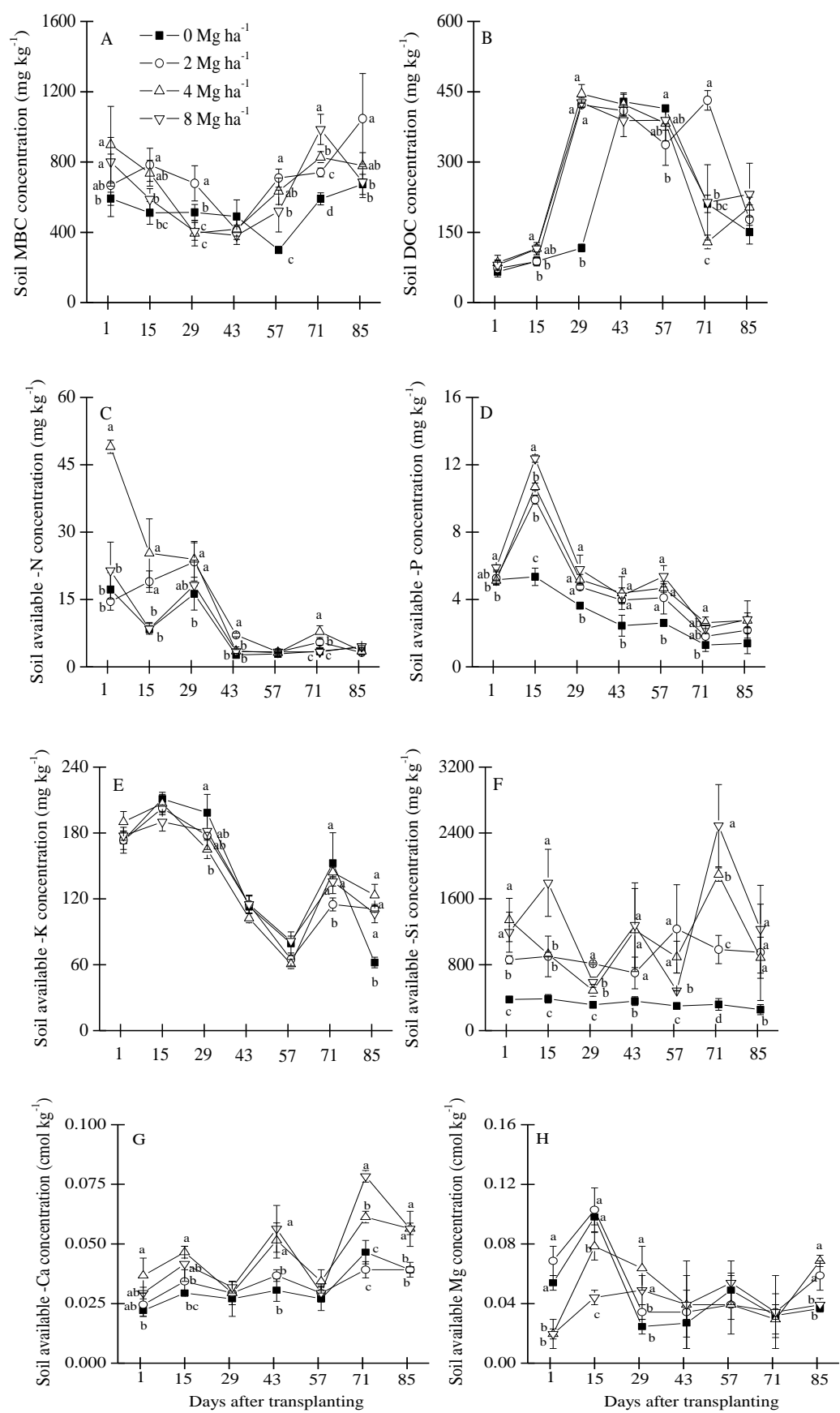

Figure S2 

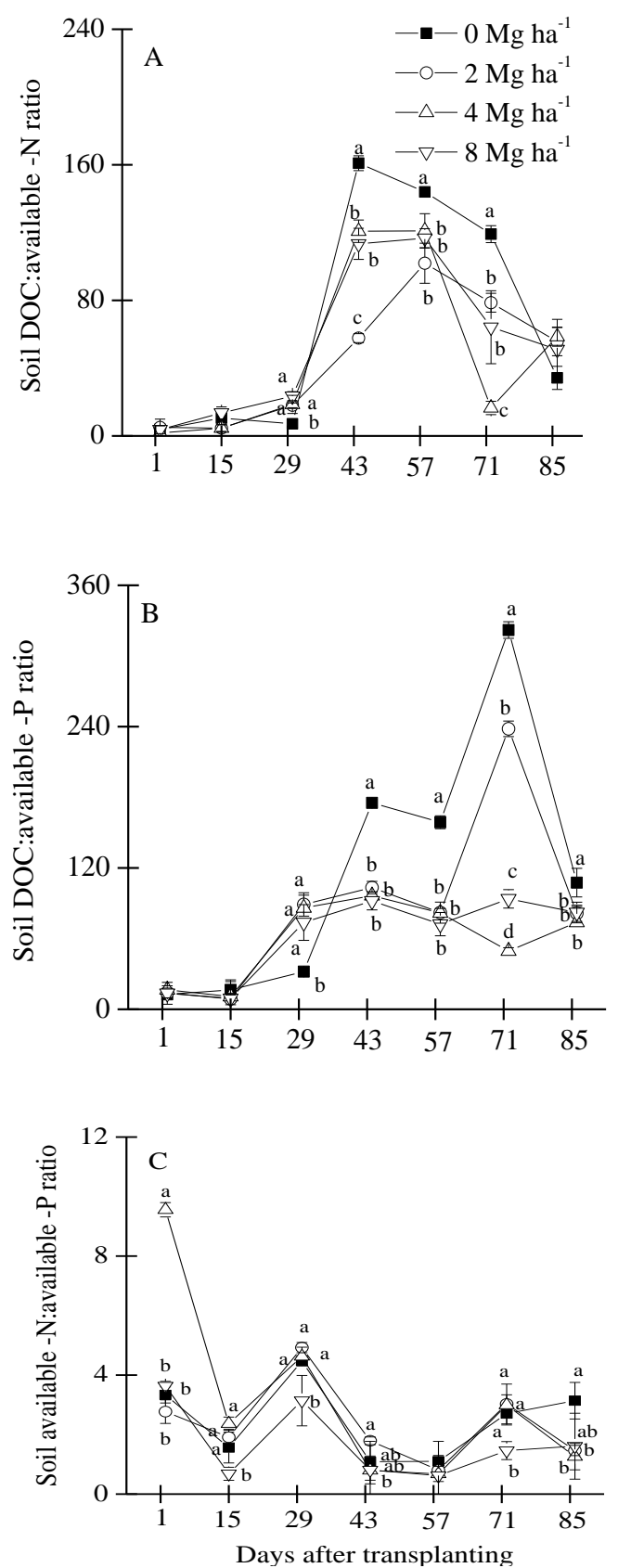

Figure S3 

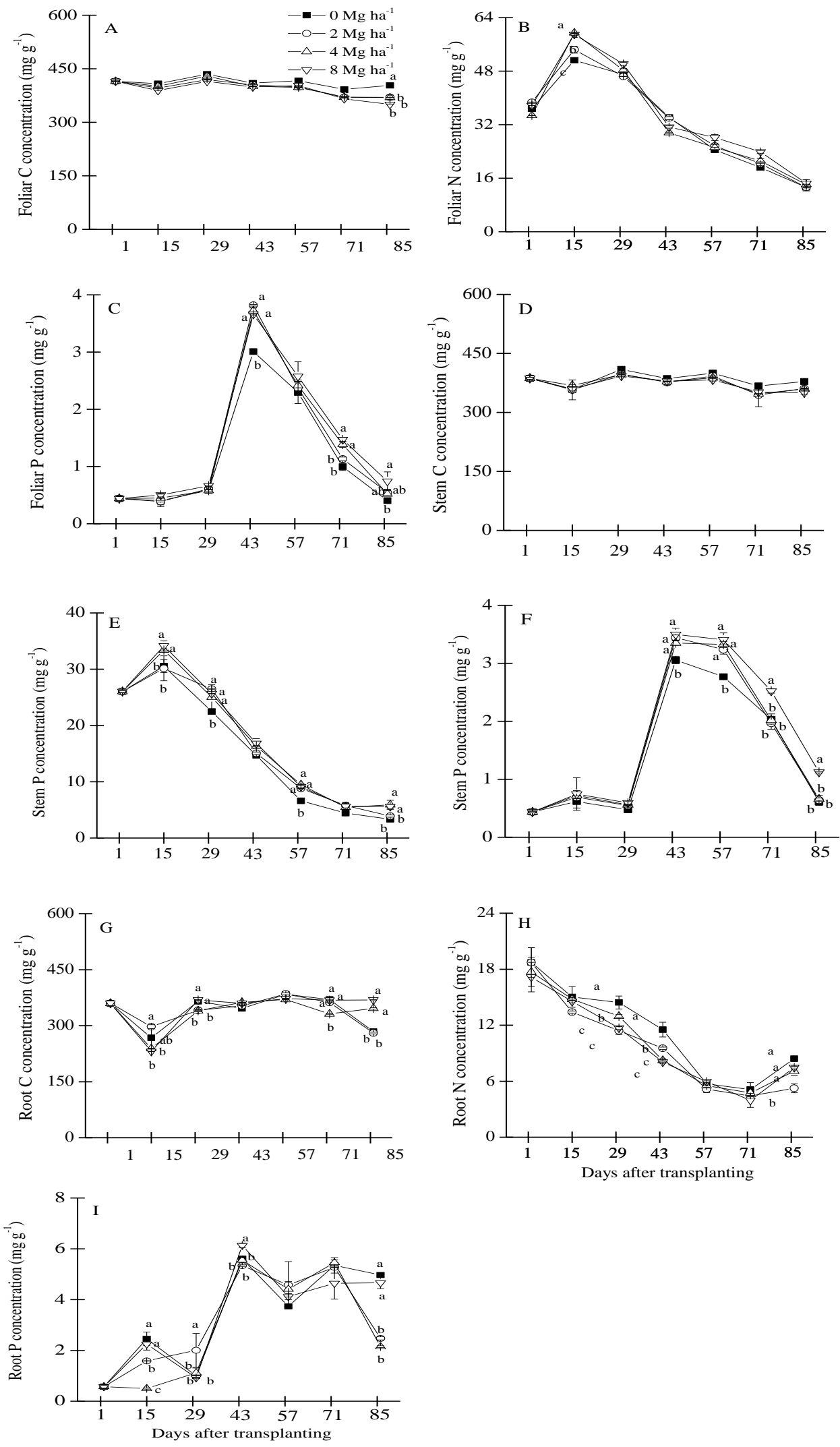

Figure S4 

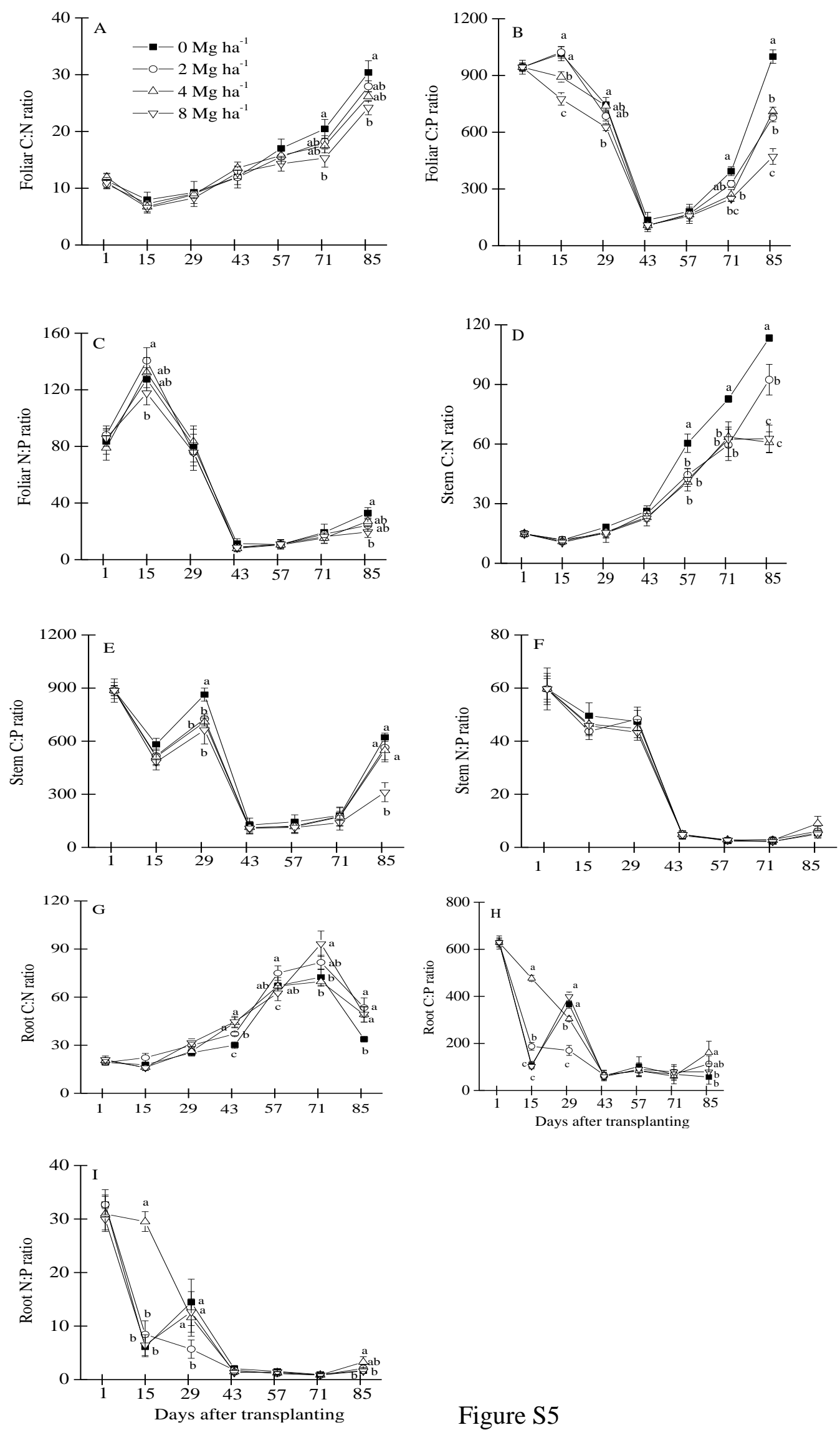

Figure S5 

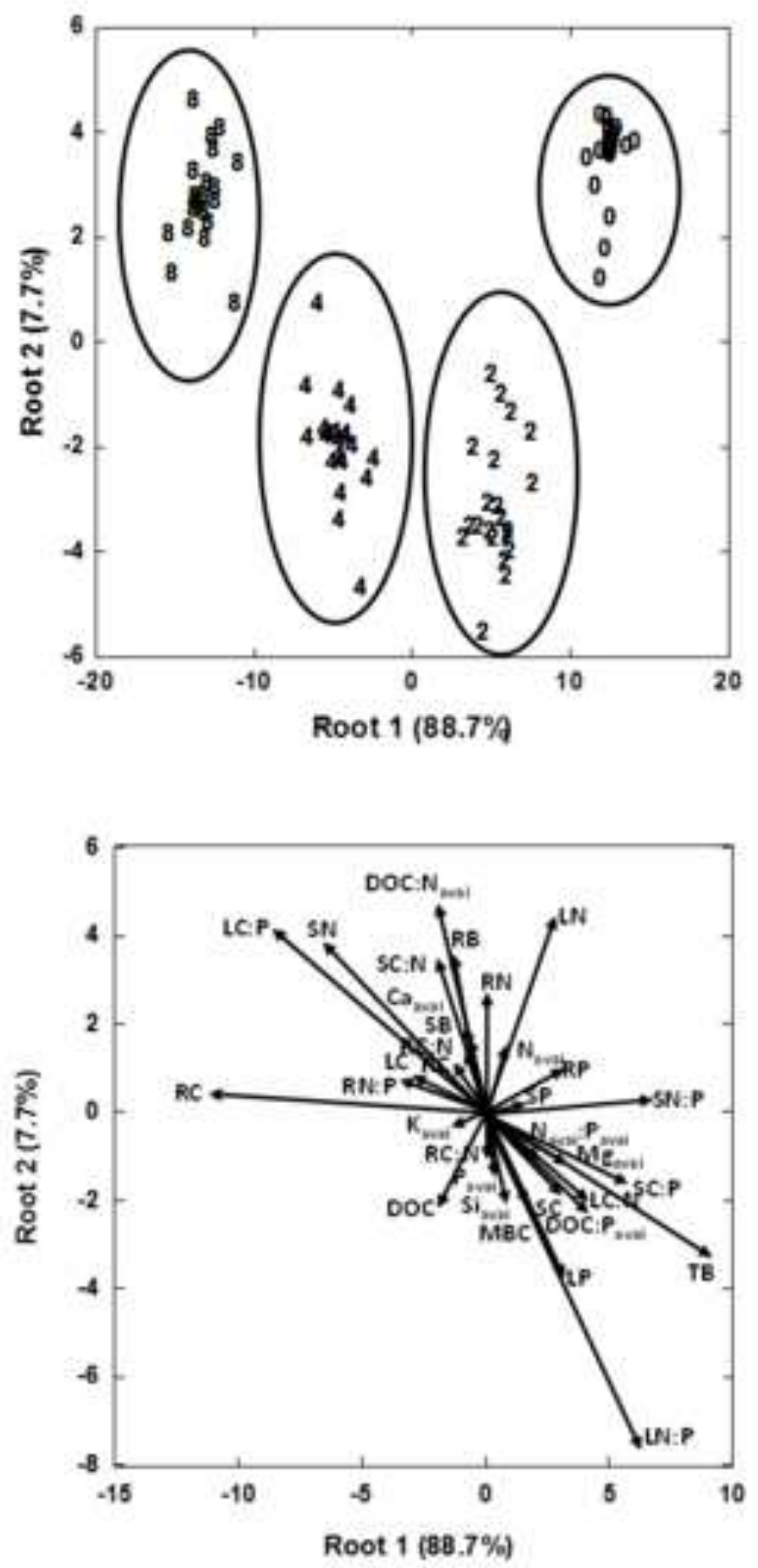

Figure 6 

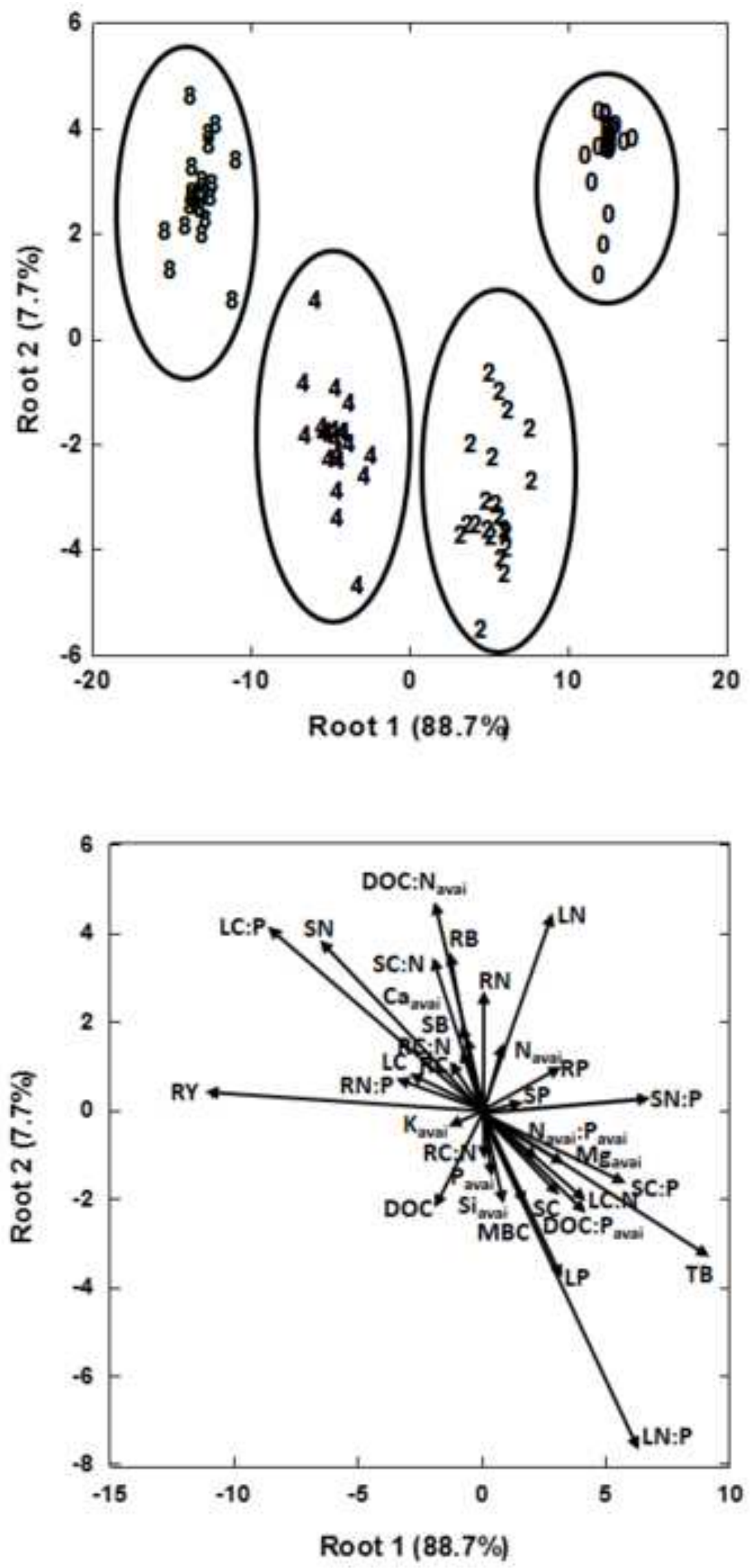


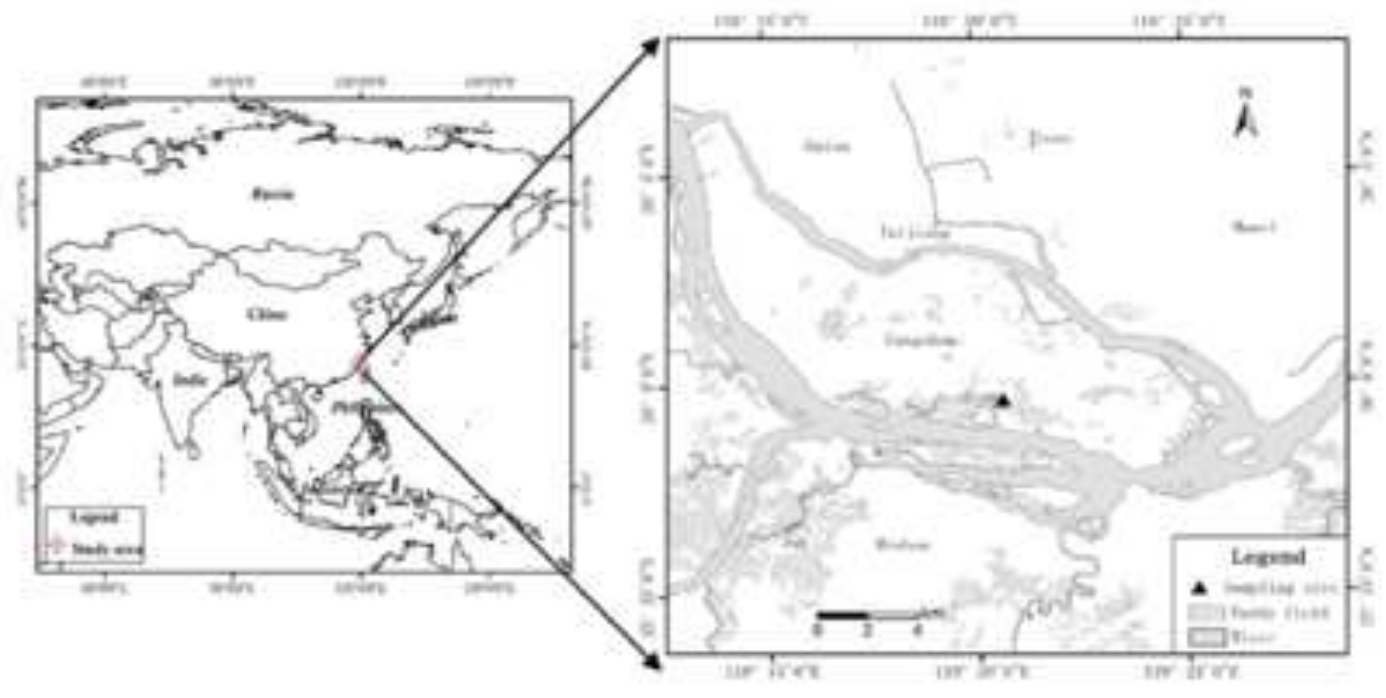

Figure 1 

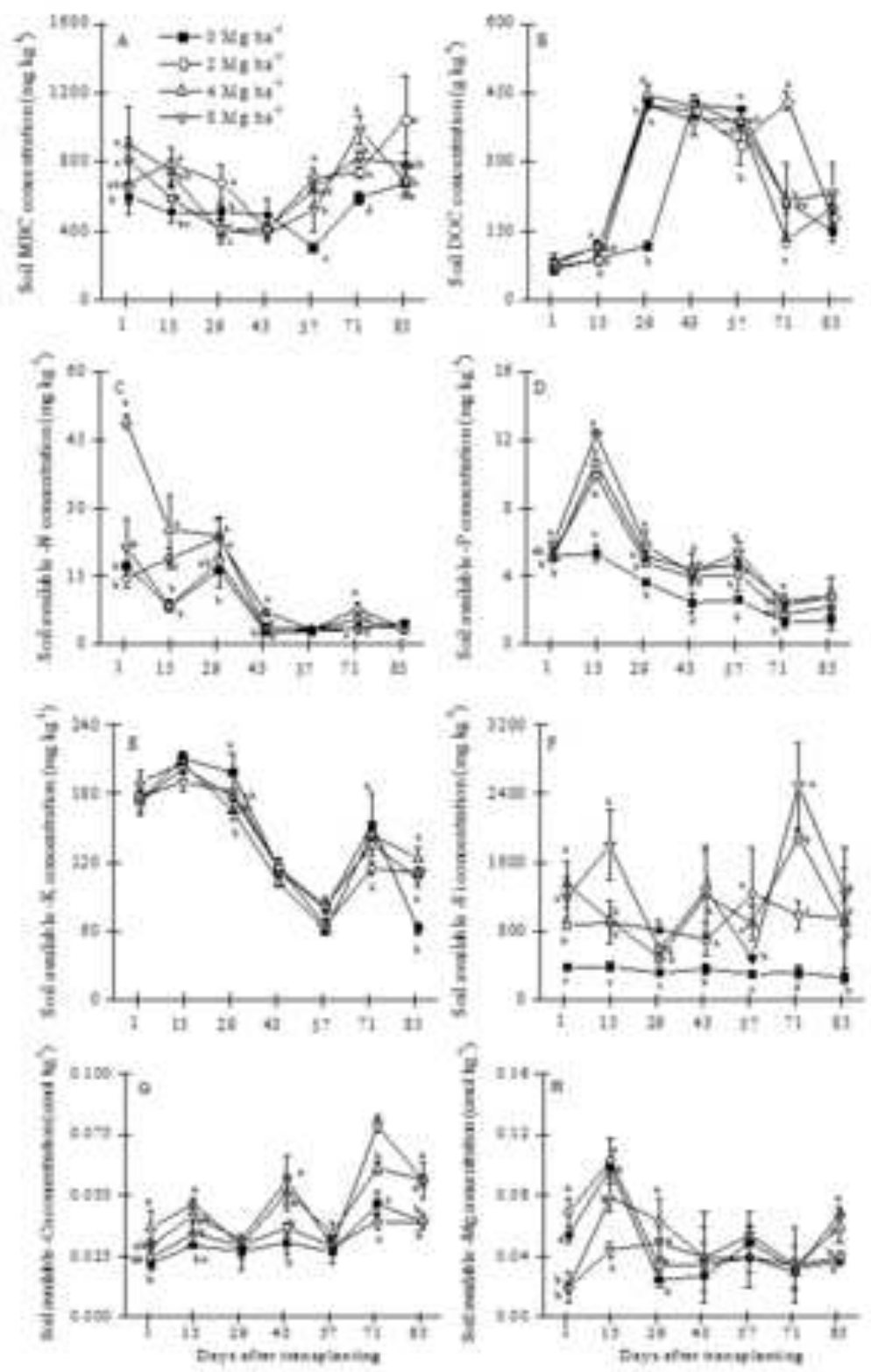

Figure 2 

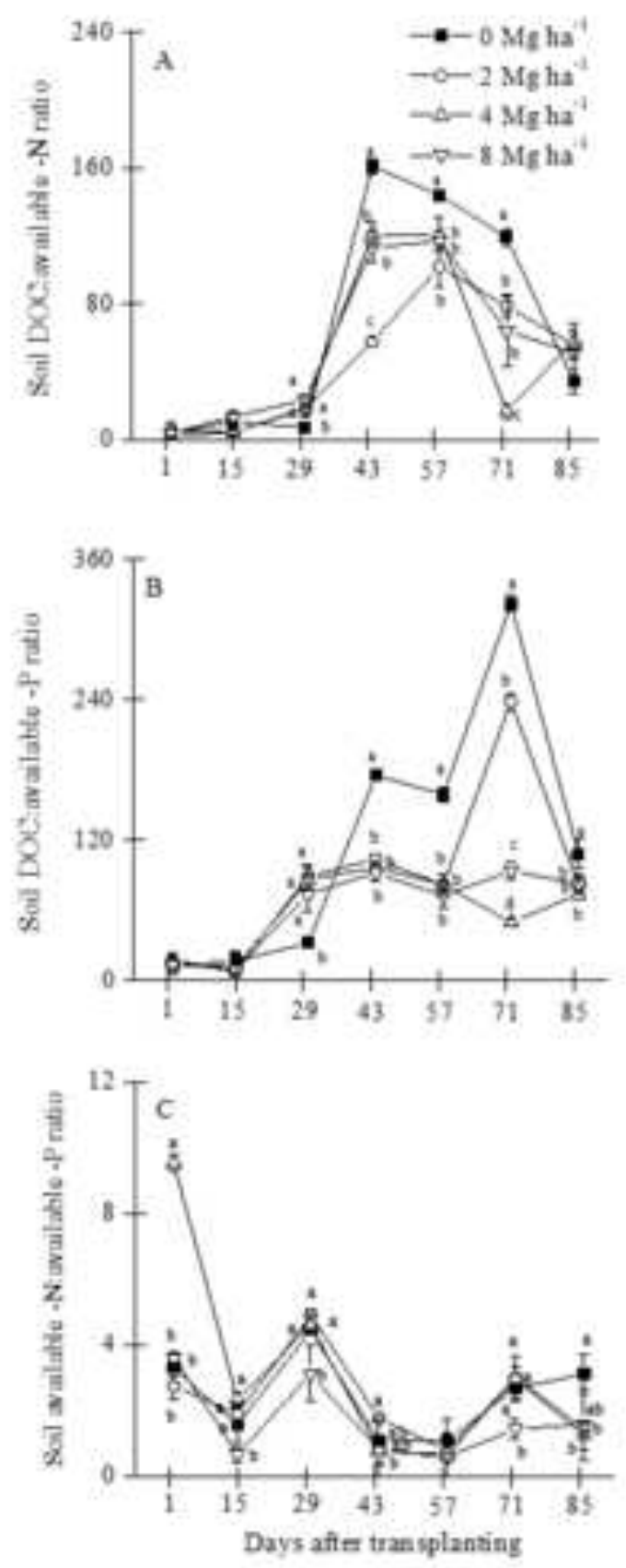

Figure 3 

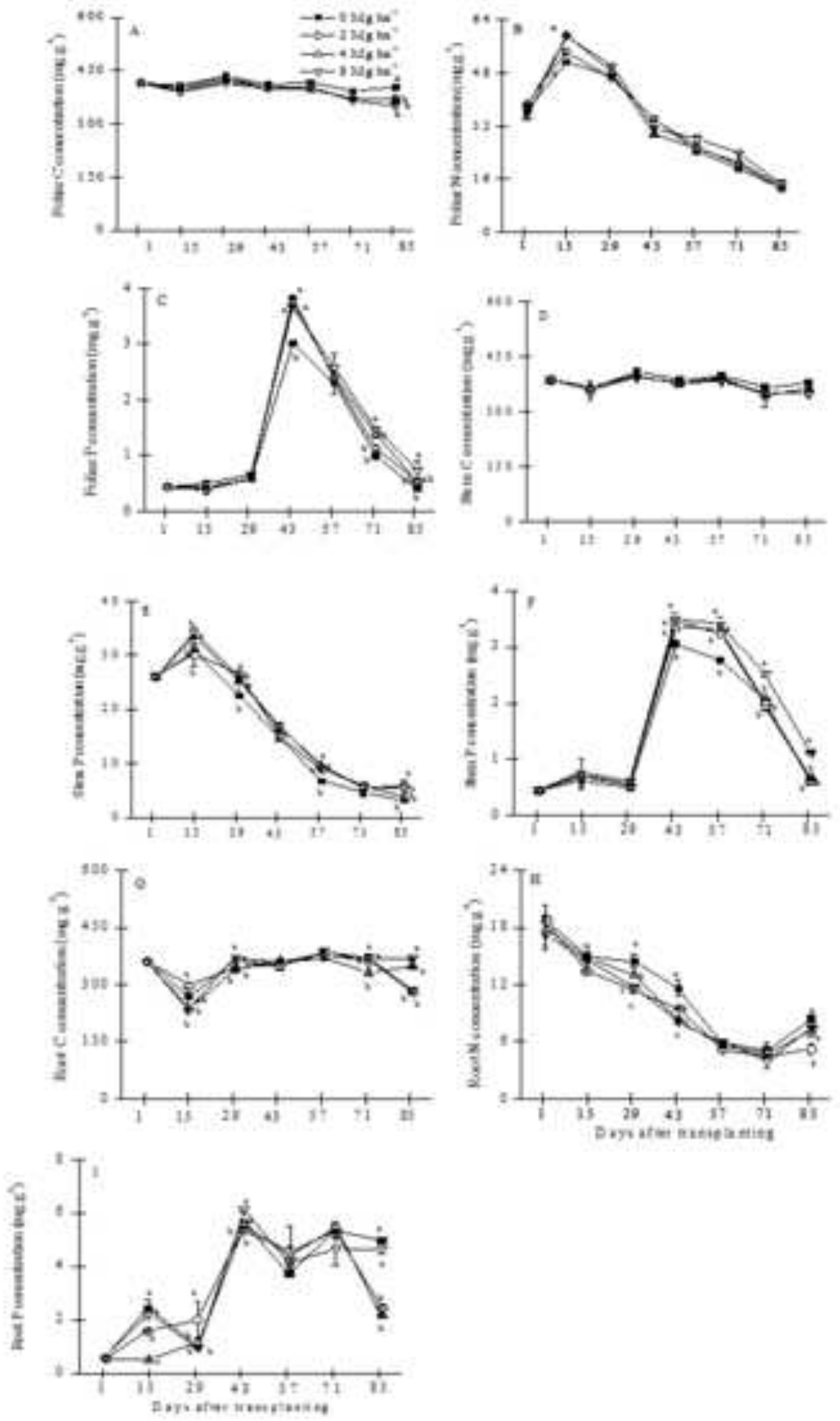

Figure 4 

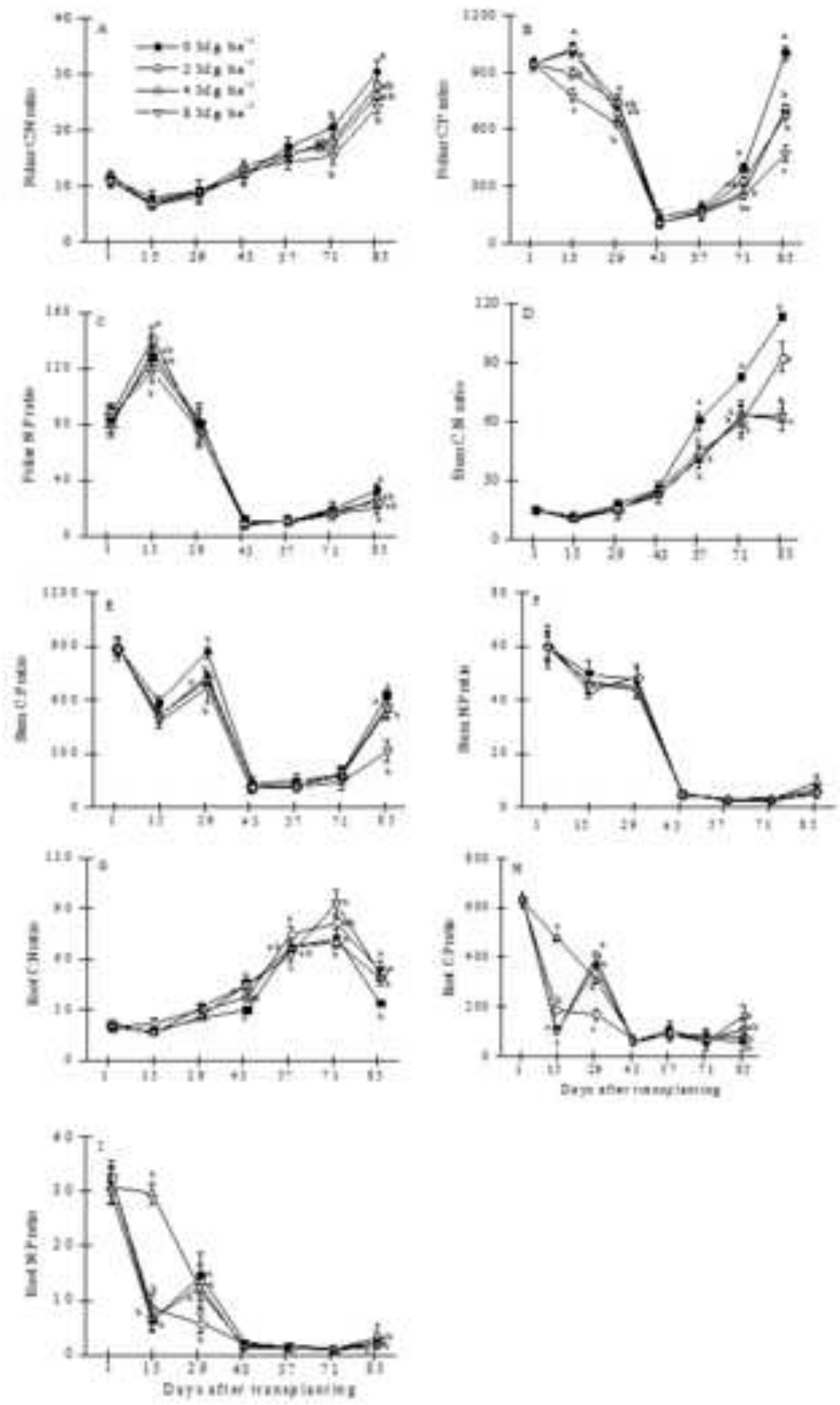

Figure 5 